\title{
An experimental evaluation of geocell and EPS geofoam as means of protecting pipes at the bottom of repeatedly loaded trenches
}

S.N. Moghaddas Tafreshi ${ }^{1,}$ *(Corresponding Author), N. Joz Darabi ${ }^{2}$, A.R. Dawson ${ }^{3}$, M. Azizian 4

${ }^{1, *}$ Corresponding Author, Professor, Department of Civil Engineering, K.N. Toosi University of Technology, Valiasr St., Mirdamad Cr., Tehran, Iran. Tel: +982188779473; Fax: +982188779476; E-mail address:nas_moghaddas@kntu.ac.ir

${ }^{2}$ PhD Candidate, Department of Civil Engineering, K.N. Toosi University of Technology, Valiasr St., Mirdamad Cr., Tehran, Iran. Tel: +982188779473; Fax: +982188779476; E-mail address: ndarabi@mail.kntu.ac.ir

${ }^{3}$ Associate Professor, Nottingham Transportation Engineering Centre, University of Nottingham, Nottingham, UK. Tel: +441159513902; Fax: +441159513909; E-mail address: andrew.dawson@nottingham.ac.uk

${ }^{4}$ MSc Graduated, Department of Civil Engineering, K.N. Toosi University of Technology, Valiasr St., Mirdamad Cr., Tehran, Iran. Tel: +982188779473; Fax: +982188779476; E-mail address: m.azizian@mail.kntu.ac.ir 
Abstract: With growing populations and continuing urban development, embedding pipes in the ground that are then over-run by traffic is inevitable. This paper describes full-scale prototype tests on high-density polyethylene (HDPE) flexible pipes (of $250 \mathrm{~mm}$ diameter), buried at shallow depth, under simulated traffic loading. The paper studies the effect of surface load diameter $(0.6 \times, 0.8 \times$ and $1 \times$ pipe diameter $)$ and the amplitude of repeated load (400 or $800 \mathrm{kPa}$ ) on pipe behavior. The effects of EPS (expanded polystyrene) geofoam block of various densities and also of geocell as a 3D reinforcement, in reducing the pressure transferred to the pipe, the deformation of the pipe and the surface settlement of the backfill were investigated. The results show that, with increase in loading surface diameter, the pipe's vertical diametral strain, the pressure transferred to the pipe and the surface settlement grow significantly, irrespective of applied pressure. Using an EPS block over the pipe, increases the soil settlement but reduces transferred pressure onto the pipe and, consequentially, results in lower pipe deformations. The increase in density of an EPS block helps improve response, but was still found to be insufficient to prevent increase in surface deflections. The use of geocell reinforcement beneath the loading surface not only reduces the pressure transferred to the pipe and decreases its deformation, but also significantly negates the tendency of the EPS block to increase the soil surface settlement. Thus, a geocell reinforcement layer placed over two EPS geofoam blocks (with a total thickness $0.3 \times$, and width $1.5 \times$, the pipe diameter) all above a pipe buried at a depth of twice pipe diameter, was found to deliver acceptable, stable response. By these means, the vertical pipe strain, transferred pressure over the pipe and soil surface settlement were reduced, respectively, by $0.45,0.37$ and $0.53 \times$ those obtained for the comparable unmodified buried pipe installation, and are within allowable limits.

Keywords: Buried pipe, geofoam block, geocell, soil surface settlement, crown pipe displacement, repetitive load 


\section{Introduction}

The safety of buried pipes under the varied loading conditions, requires that their response and that of the overlying materials used in construction, be well described. To obtain such a description, field studies, numerical analysis or experimental studies can be performed, each method providing different insights into the pipe response and aiding, more, or less, understanding and predictive capabilities. Readers interested in finding out more are referred to work performed by Arockiasamy et al. (2006), Moghaddas Tafreshi and Khalaj (2008), Talesnick et al. (2011), Moghaddas Tafreshi et al. (2012), Srivastava et al. (2013), Anil et al. (2015), Hegde and Sitharam (2015a), Tavakoli Mehrjardi et al. (2015), Beju and Mandal (2017), Meguid and Hussein (2017) and Elshesheny et al. (2019a;b).

It is known that increases or decreases in the stresses experienced by pipes can occur due to the arching phenomenon (Spangler 1941) in response to the covering material's self-weight or to loading at the ground surface (static or repeated). Rigid pipes provide a stiff inclusion in the ground that attracts vertical stress to the crown, generates a vertical stress 'shadow' either side of the pipe and hinders settlement over the pips. The adjacent soil prisms tend to settle, leading to downward shear stress on the soil prism containing the pipe. The term given for this behavior is negative soil arching. On the other hand, flexible pipes deform easily under the vertical overburden and surface loads so that the settlement of the pipe crown and the central soil prism is larger than either side of the pipe. Hence vertical stress acting on the pipe crown drops and is carried, instead, by the stiffer soil prisms in either side of the pipe, inducing upward shear stresses on the pipe's soil prism. The term given for this behavior is positive soil arching.

Where stiff pipes are used, compensatory compressible materials have been proposed as covering soils or soil replacements. In this way, both the central and adjacent prisms might gain similar vertical stiffnesses and the vertical stresses and deflections are returned to an approximately uniform state (McAfee and Valsangkar 2004; Kang et al. 2008a;b), thereby reducing pipe crown loading without increasing its deflection.

Compaction of pipe cover, usually in an excavated trench, is typically difficult and consistency is unreliable. Where it is desired that this fill has a certain compressibility, for the reasons just described, the task may become even more challenging. A possible remedy is to use expanded polystyrene (EPS) geofoam block. This material has complete uniformity due to its manufacturing method and can be purchased with specific compressibility and other engineering properties. Furthermore, its low Poisson's Ratio means that it will not undesirable shed load to adjacent soil prisms. For these reasons it has been used in a range of geotechnical 
applications - e.g. in embankment construction, over pipes and in culvert and other retaining walls (Duškov 1997; Zou et al. 2000; Zarnani and Bathurst 2007; Vaslestad et al. 2008; Farnsworth et al. 2008; Hatami and Witthoeft 2008; Barrett and Valsangkar 2009; Horvath 2010; Newman et al. 2010; Bartlett et al. 2015; Witthoeft and Kim 2015; Meguid et al. 2017a,b; Al-Naddaf et al. 2019).

A few researchers used EPS geofoam blocks as protection for buried pipes. The use of EPS geofoam blocks over a small corrugated steel pipe (100 mm diameter) was examined by Kim et al. (2010). They performed full-scale tests in the laboratory at three surcharge levels, with one EPS layer (having a thickness $0.5 \times$, and a width $1.5 \times$, pipe diameter) and observed a reduction of as much as $73 \%$ in the vertical pressure on the pipe crown. They attributed this to a positive arching action. Numerical analysis of the same general arrangement was performed by Witthoeft and Kim (2015), once again with static loading of the backfill surface. Their results confirmed the physical ones of Kim et al. (2010) where a covering EPS geofoam block (thickness $=0.5 \times$ pipe diameter, width $=1.5 \times$ pipe diameter) is most effective in reducing the vertical stress on the pipe's crown. A combination of fly ash backfill and EPS geofoam was used to provide a compressible inclusion in model tests reported by Beju and Mandal (2017). They also used a jute geotextile to provide reinforcement of the ash. Their paper lists reductions of up to $94 \%$ in vertical stress and $73 \%$ in strain for this combination of materials and reinforcement depending on EPS density and depth to pipe crown.

Despite these advances in our understanding, as well as the work of Vaslestad et al. (1993) and Anil et al. (2015), the effect of an EPS block on pipe deformation and its possible disadvantages in increasing the soil surface settlement is still uncertain. High deformations of the central soil prism and low surface modulus of elasticity might be problems that would limit practical use. In addition, there appears to be little literature covering response of such systems under repeated loading.

Cellular geosynthetic materials ('Geocells') have been proven to be effective at increasing bearing capacity and reducing rutting and settlement of backfill due to the lateral confinement provided by cellular system (Dash et al. 2007; Madhavi Latha and Rajagopal 2007; Madhavi Latha et al. 2009; Dash 2012; Leshchinsky and Ling 2012, 2013; Indraratna et al. 2015; Moghaddas Tafreshi et al. 2016; Trung Ngo et al. 2016; Satyal et al. 2018; Tavakoli Mehrjardi et al. 2019). Tavakoli Mehrjardi et al. (2012), Hegde and Sitharam (2015a) and Khalaj et al. (2017) showed that passive stress and frictional resistance developed between the geocell walls and soil gave the soil a greater load-spreading ability that could act to reduce the pressure imposed 
on the pipe, the soil surface settlement and deformations in the buried pipe under both static and repeated loading.

Therefore, the overall aim of the study reported in this paper was to investigate the performance, in terms of load capacity, surface settlement and pipe deformation, of installations combining geocell reinforcement with EPS as a compressible backfill.

\section{Objectives}

As outlined above, successful buried pipe installations will be those where the pipe is protected from excessive stresses and/or deformations and where the ground surface does not suffer excessive deformation under loading. Geocells can achieve the former as reported in the literature referred to a few lines earlier in this paper and can reduce rutting (Mamatha and Dinesh 2019). Laboratory and field tests of backfill material(s) are commonly performed as a key means of assessing the likelihood of failure of such installations. In this paper the problem is investigated in unreinforced installation by varying the following inputs:

- the magnitude of the stress applied repeatedly to the soil surface,

- the size (diameter) of the surface load, and

- the depth of embedment of the pipe

and quantifying the resulting outputs:

- $\quad$ soil surface settlement (SSS),

- the vertical stress applied by the backfill onto the pipe's crown and

- the vertical diametral strain $(V D S)$ of the pipe, which is defined as the reduction in vertical diameter divided by the pipe diameter

as the relationship between these inputs and outputs has not been, previously, the subject of extensive study. Where previous papers have studied these relationships for the application of EPS blocks over buried pipes, it has been static, rather than repeated, loading (e.g. Vaslestad et al. 1993; Kim et al. 2010; Witthoeft and Kim, 2015; Beju and Mandal 2017), or geogrid/geocell reinforcement without EPS geofoam blocks (e.g. Moghaddas Tafreshi and Khalaj 2008; Tavakoli Mehrjardi et al. 2012; Hegde and Sitharam 2015a; Kou et al. 2018) that formed the topic matter.

To study the influence of load plate diameter, depth of pipe embedment and the magnitude of the repeated loading applied on buried pipe systems, several large-scale, unreinforced installations were tested. 
Additional tests investigated similar arrangements, but with the addition of geocell layer and EPS blocks over the pipe. The purpose was to meet the following key objectives:

- Investigate overall response,

- Investigate the influence of load plate diameter on unreinforced system response,

- Assess the effects of amplitude on the response of the unreinforced system when the load is repeated,

- Evaluate the effect of depth of pipe on the response of the unreinforced system,

- Investigate the effect of EPS block density on the response of the unreinforced system,

- Investigate the influence of the addition of geocell reinforcement,

- Investigate the influence of the combined addition of EPS block(s) and geocell reinforcement,

Only a single type of pipe, geocell, soil and three densities of EPS material were used. It is to be expected that the results would need adapting and interpreting before they can be applied to similar buried pipe installations in different soils and with different EPS densities and geosynthetic properties.

\section{Materials}

Soil

To simulate the natural ground that would provide the pipe bedding and the two vertical sides of the backfill trench, a soil with maximum grain size of $20 \mathrm{~mm}, 12.5 \%$ passing the number 200 sieve, a specific gravity of $2.67\left(G_{s}=2.6\right)$, a liquid limit $(L L)$ of 22 and a plastic limit (PI) of 8 was used (Fig. 1). According to the Unified Soil Classification System (ASTM D2487-11), this soil is classified as poorly-graded sand with clay $(S P-S C)$. The maximum dry density and optimum moisture content (ASTM D1557-12) of this soil were obtained as $19.35 \mathrm{kN} / \mathrm{m}^{3}$ and $7.2 \%$, respectively. The angle of internal friction $(\varphi)$ and cohesion (c) of the soil, obtained by consolidated undrained triaxial compression testing at a bulk density of $18.67 \mathrm{kN} / \mathrm{m}^{3}$ (corresponding to $90 \%$ of maximum dry density with moisture content of $7 \%$, as compacted in native soil layers) were respectively $\sim 37^{\circ}$ and $8 \mathrm{kPa}$.

In order to best simulate reality for backfill trench, a granular soil that satisfies the grain size limits for pipe backfill materials (ASTM D2321-08) was used as shown in Fig. 1. This soil was used to fill around the two sides and over the crown of the pipe, to cover the EPS block and, where each was used, to fill the geocell pockets, as shown in Fig. 4c. The soil had a specific gravity equal to $2.66\left(G_{s}=2.66\right)$ with a maximum and mean grain size of $20 \mathrm{~mm}$ and $4.1 \mathrm{~mm}$, respectively. Based on the specifications of Unified Soil Classification System 
(ASTM D2487-11), the soil is classified as a well-graded sand (SW). According to the modified Proctor compaction (ASTM D1557-12), the maximum dry density and optimum moisture content of this soil were obtained as $20.42 \mathrm{kN} / \mathrm{m}^{3}$ and $5.1 \%$, respectively. The angle of internal friction $(\varphi)$ of the soil, obtained by consolidated undrained triaxial compression testing at a bulk density of $19.72 \mathrm{kN} / \mathrm{m}^{3}$ (corresponding to $92 \%$ of maximum dry density with moisture content of 5\%, as compacted in backfill soil layers) of specimens was $40.5^{\circ}$.

Pipe

High density polyethylene pipe (HDPE 100) that complies with BSI 4660 (2000) for underground sewers, irrigation of agricultural lands, fire station pipe lines and drainage services having an external diameter (D) of $250 \mathrm{~mm}$ with a wall thickness $(t)$ of $4 \mathrm{~mm}$ was used. According to the manufacturer (Gostaresh Co.), this pipe has an elastic modulus of $1000 \mathrm{MPa}$, a Poisson's ratio of 0.3 and a weight per unit length of $4.83 \mathrm{~kg} / \mathrm{m}$. The pipe length of $1740 \mathrm{~mm}$, was chosen approximately equal to the length of the trench in the full-scale prototype test (see Figs. 3a and 4a).

\section{EPS geofoam block}

In several installations, EPS geofoam blocks were used over the pipe in addition to the backfill sand, by replacing some of the deeper sand over pipe. The EPS blocks had a rectangular-shaped with two thicknesses (0.3 and 0.6 times the pipe diameter, $D$ ), three widths of $1 \mathrm{D}, 1.5 \mathrm{D}$ and $2 \mathrm{D}$ and a length of $1740 \mathrm{~mm}$, approximately equal to the length of the trench and pipe. They were placed parallel to the pipe axis. Three densities of EPS were used: 20,30 and $40 \mathrm{~kg} / \mathrm{m}^{3}$. The elastic limits and compressive strengths of EPS geofoam were obtained from unconfined uniaxial compressive tests (ASTM D1621-10) on $200 \mathrm{~mm}$ cubic specimens (Ghotbi Siabil et al., 2019), at each density. Elastic limit is defined as the stress at $1 \%$ strain and the compressive strengths as the stress at $10 \%$ strain (Horvath 1994). To evaluate the angle of internal friction and apparent cohesion in each density of EPS blocks, unconsolidated undrained (UU) triaxial tests under confining pressure of 50, 100 and $150 \mathrm{kPa}$ cell pressures were performed. All EPS geofoam block samples had a diameter and height of 75 and $150 \mathrm{~mm}$, respectively. The axial load with a constant strain rate of $1.5 \mathrm{~mm} / \mathrm{min}$ was applied (ASTM D2850-15). Table 1 shows the physical and mechanical properties of EPS blocks with three different densities. This EPS geofoam is comparable to those used in other research (e.g. Stark et al. 2004) in terms of variation of compressive strength with EPS density. 


\section{Geocell}

The primary function of a geocell is reinforcement in which the cell walls act as membranes that confine the soil inside each cell thereby developing a more competent soil layer. The component geosynthetic that forms the cell walls can be of any convenient construction (non-woven, geomembrane, geogrid, etc.) so long as it provides good confinement to the enclosed soil. The geocell selected for the experiments described here has a honeycomb three-dimensional shape with non-perforated walls comprised of heat-bonded non-woven polymeric geotextiles. Filling, and fully compacting, the pockets of the geocell with soil develops wall-soil frictional interaction and expands the cells so that a passive confining pressure becomes available increasing the effective stress, and hence the strength and stiffness, of the confined soil. The geocell used has a pocket size of $110 \times 110$ $\mathrm{mm}$ and a height of $100 \mathrm{~mm}$. When spread out, it covered a width of about 5 times the loading plate ( $b=5 D=1250 \mathrm{~mm}$ ), centered on the axis of loading and a length of $1740 \mathrm{~mm}$, equal to the length of the pipe. Table 2 tabulates the engineering properties of this geotextile to form the geocell, as listed by the manufacturer "DuPont de Nemours" and Fig. 4c shows an isometric view of the geocell during the backfilling process, below final surface level.

\section{Test layout}

Laboratory tests, similar to full-scale field arrangements, of buried pipes were achieved using a physical, three-dimensional large-scale prototype. A test trench containing the pipe, EPS blocks and geocell layer, were prepared in a rigid test pit with plan dimensions of $2200 \mathrm{~mm} \times 2200 \mathrm{~mm}$ and depth of $1000 \mathrm{~mm}$ and refilled by backfill soil as shown in Fig. 2 and Fig. 4d.

\section{Test pit and simulated repeated load}

According to ASTM D2321-08 recommendation, the width of the trench should be at least equal to $W=1.25 D+300(\mathrm{~mm})$. Based on AASHTO (2010), the minimum width of the trench should be greater than $W=1.5 D+305$ and $W=D+406$. " $D$ " and " $W$ " are respectively pipe diameter and the required trench width in mm. To satisfy these requirements for the pipe diameter, $D$, of $250 \mathrm{~mm}$, a trench width, $W$, of $750 \mathrm{~mm}$ and length of $1740 \mathrm{~mm}$ was selected (Fig. 2). The trench depth varies depending on the embedment depth of the buried pipe $(1.5 D=375 \mathrm{~mm}$ and $2 D=500 \mathrm{~mm})$. The maximum depth of buried pipe for the tests, was selected $2 D=500 \mathrm{~mm}$ as proposed by Moghaddas Tafreshi and Tavakoli (2008) for the pipes in geogrid reinforced soil. When geocell is used, it is stretched across the top of the trench and extends approximately $250 \mathrm{~mm}$ over the parent soil, either 
side of the trench). Fig. 2. depicts the schematic view of the test setup including hydraulic jack, buried pipe, instrumentation and parameters used in the experiments.

The loading system consists of a hydraulic cylinder jack, a controlling unit and a loading frame. The loading frame comprises a fixed horizontal strong reaction beam on two strong steel columns that supports the hydraulic actuator. The hydraulic cylinder and controlling unit are able to produce monotonic or repeated loads up to $100 \mathrm{kN}$. Generally, the tire print shape depends on the tire construction, inflation, wheel load and the stiffness of the ground and usually varies between circle and rectangle (Saarilahti 2002). Although some researchers used a rectangle plate (Elshesheny et al. 2019a;b), it is more common to use a circular plate (Thakur et al. 2012; Brito et al. 2009; Tingle and Jersey 2007; Moghaddas Tafreshi et al. 2014) to investigate the performance of pavement under traffic loadings. In addition, ASTM D1195-09 stipulates the use of a circular rigid steel plate having a diameter between 152 and $762 \mathrm{~mm}$ for repetitive static plate load tests when evaluating or designing flexible airport and highway pavements. Hence, in the present testing program, circular plates with diameters of 150, 200 and $250 \mathrm{~mm}$ are used on the backfill surface.

In all tests and in order to replicate half and full traffic loadings, 150 cycles of repeated loading with amplitude of 400 and $800 \mathrm{kPa}$ respectively (Brito et al. 2009) and frequency of $0.33 \mathrm{~Hz}$ were applied to the on circular loading plate. Tire pressures recommended by Brito et al. (2009) are what a vehicle imposes on road (regardless of road type), although Brito et al. (2009) used them for an unsealed road - i.e. exactly the sort of construction considered in the current tests. Furthermore, these stresses are those that would be imposed on a layer covering a trench during construction when there is not yet any flexible or rigid pavement layer overlying the surface of the soil. Although, the reduced traffic load values were considered by several researchers (Moghaddas Tafreshi and Khalaj 2008; Elshesheny et al. 2019a;b), conventional traffic load values are likely to be the critical loading on the surface of backfill soil. Hence the adoption of Brito et al. (2009) values here. According to preliminary repeated load tests, the rate of change in measured variables became, approximately, stable within 150 load cycles or became unstable prior to 150 load cycles.

\section{Measurement system}

The average settlement of the loading plate during loading, unloading and reloading, was measured by two linear variable differential transducers (LVDTs) with an accuracy of $0.01 \%$ of full range (100 mm), attached to opposite edges of the loading plate (Fig. 2 and Fig. 4d). 
To measure the vertical diametral strain $(V D S)$ during the test, five LVDTs with an accuracy of $0.01 \%$ of full range $(50 \mathrm{~mm})$ were installed inside the pipe, using a steel channel having a U-profile installed inside the pipe to make a solid base on which to fix the LVDTs (by magnet base/rod- see Fig 3b). In all tests, one LVDT was installed at the mid-point of the pipe length to measure the vertical diametral strain (VDS). In several tests (the tests described in in Table 3), four additional LVDTs were installed inside the pipe to measure the vertical deflection of the pipe crown $(V D S)$ along the pipe's axis at distances of 150, 300, 450 and $600 \mathrm{~mm}$ from the mid-point of the pipe's length which was underneath the center of the loading plate.

The transferred pressure to the pipe crown was measured using one pressure cell having a diameter of 50 $\mathrm{mm}$ and an accuracy of $0.01 \%$ of its full range of $1 \mathrm{MPa}$, installed on the crown of the pipe (Fig. 2 and Fig. 3a). Fig. $3 \mathrm{a}$ and Fig. 3b provide respectively a schematic of the pressure cell over the pipe and a photograph of the LVDTs inside the pipe in the middle and along the pipe's axis. To ensure the accuracy of the recorded data all of the LVDTs, load cell and pressure cell were calibrated using the manufacturer's approved method.

A PC-based data acquisition system records the output data streams from load cell, pressure cell and LVDTs and presents them for future analyses. The applied repeated load was measured by placing an S-shaped load cell, with an accuracy of $\pm 0.01 \%$ and a full-scale capacity of $100 \mathrm{kN}$ between the hydraulic jack and loading plate (Fig. 2 and Fig. 4d).

\section{Backfill preparation and test procedure}

The simulated native soil that forms the bedding and the two sides of the trench (Fig. 2) was compacted in layers $100 \mathrm{~mm}$ thick, each by three passes of a walk-behind vibrating plate compactor, $450 \mathrm{~mm}$ in width. To provide the soil masses either side of the trench with an approximate vertical side (Fig. 2), a vertical stiff wooden shutter was employed. The soil was compacted so as to ensure that a bulk density of $18.76 \mathrm{kN} / \mathrm{m}^{3} \mathrm{was}$ achieved. In the case of disturbance of the native soil by the loading of previous test or during removing the backfill soil to prepare the next test, the simulated native soil was reconstructed.

Before backfill preparation, LVDT(s) were installed inside the pipe (Fig. 2) and the pipe placed on the surface of the trench (Fig. 4a). The unreinforced backfill layers over the pipe were compacted using a walkbehind vibrating plate compactor, $450 \mathrm{~mm}$ in width. The required bulk unit weight for backfill over the pipe was $19.72 \mathrm{kN} / \mathrm{m}^{3}$ - a density equivalent to $92 \%$ of maximum dry unit weight at an optimum moisture content of $5 \%$. To achieve this, the soil layers were prepared and compacted at thickness of 50 and $75 \mathrm{~mm}$, respectively by one and two passes of the compactor, depending on the thickness of EPS block $(0.3 D$ and $0.6 D)$. Although the same 
compaction method has been applied for preparation of unreinforced and geocell-reinforced layers, the maximum soil density that is practical to achieve inside the pockets of the geocell layer is less than in unreinforced soil (i.e. unreinforced layers and the soil outside the cells of geocell). The vertical webs of the geocell provide frequent barriers to intimate packing and hinder vertical soil densification in geocell pockets, compared with unreinforced soil. Hence, lower soil density inside the geocell pocket would be expected for the same, even for substantial compactive effort. This feature has been reported in previous studies on geocellreinforced backfill (Thakur et al. 2012; Tavakoli Mehrjardi et al. 2012). Thus, compaction of the soil inside the geocell's pockets with four passes of the compactor achieved a bulk unit weight of about $19.2 \mathrm{kN} / \mathrm{m}^{3}$ at a moisture content of $5 \%$ (corresponding to $\approx 90 \%$ of maximum dry unit weight) was achieved. However, the test results show that, despite this limitation, the trench reinforced by geocell layer provided an effective installation to attenuate pipe deformation, soil surface settlement and pressure on pipe as compared with unreinforced installation.

The soil mass around both sides of the pipe was carefully compacted by dropping a tamper with weight of $5 \mathrm{~kg}$ on a rigid steel plate with dimension of $240 \times 240 \mathrm{~mm}$ from a height of $300 \mathrm{~mm}$, three times, on the soil surface at two levels: at the level of the horizontal pipe diameter and at the level of the pipe crown. This provided a bulk unit weight of soil approximately $17 \mathrm{kN} / \mathrm{m}^{3}$. Dropping the tamper more than three times caused no significant increase in soil unit weight. To assess the backfill density, in some installations and after backfill placement, the unit weights of unreinforced layers and the soil inside the pockets of geocell layer were measured according to ASTM D1556-07. The densities measured in several tests by sand-cone tests revealed a close match with maximum differences in results of $\approx 2-3 \%$. This difference seems to be small for geotechnical applications.

As the backfill was placed and compacted to the top of pipe, the pressure cell on the crown of the pipe was installed. In order to provide space for the pipe-crown pressure cell, the location of geofoam block is $20 \mathrm{~mm}$ above pipe crown. When the backfill was complete, the rigid loading plate with specified diameter (150, 200 and $250 \mathrm{~mm}$ ) and thickness of $25 \mathrm{~mm}$ was placed over the center of trench and the load cell and two LVDTs were installed to record the displacement of the loading plate. Fig. $4 \mathrm{a}$ and $4 \mathrm{~b}$ shows the pipe and the EPS block over the pipe. Fig. $4 \mathrm{~b}$ and $4 \mathrm{c}$ shows a view of the geocell layer during the backfill preparation, below final surface level and just prior to loading, respectively. 


\section{Test parameters and testing program}

Fig. 5 shows schematic views of the different backfill installations. The unreinforced backfill without EPS block (Fig. 5a) is considered to investigate the effect of diameter of the loading surface (d/D), amplitude of the applied repeated load and pipe embedment depth $(Z)$. The unreinforced backfill with EPS block (Fig. 5b) is considered to investigate the effect of density, thickness $\left(h_{e}\right)$ and width $(w)$ of EPS geofoam block. The effect of geocell layer beneath the loading surface is investigated by the installations illustrated in Fig. 5c and 5d, respectively for single and two layers of EPS blocks. Table 3. lists the test parameters and testing program adopted to investigate the surface settlement and response of buried pipe supported by geofoam block and geocell layer when subjected to repeated loads. A total of 23 loading tests (14 independent and 9 replicate tests) investigated the effect of diameter of the loading surface, amplitude of the applied repeated load, pipe embedment depth, density and thickness of EPS geofoam block, geocell reinforcement and number of EPS blocks. The results of replicate tests show the maximum differences of the repeated tests are limited to $6 \%$, which might be due to the minor variations in soil layers' compaction or in the accuracy of the measurement systems.

\section{Results and discussions}

\section{Overall behavior of buried pipe system}

Two general types of pipe vertical diametral strain (VDS) and soil surface settlement (SSS), variations were observed under the application of loading cycles, characterized as stable: where no excessive VDS or SSS occurs during cyclic loading, or unstable: where excessive VDS or SSS (or failure) results under cyclic loading.

The typical pressure-VDS and pressure-SSS variations are respectively shown in Fig. $6 \mathrm{a}$ and b, for both stable and unstable conditions. This figure shows that a large proportion of total VDS and SSS occurs in the first cycle. In the stable condition, both VDS and SSS reach an approximately resilient response after only a few additional load cycles. Accumulation of additional plastic strain/settlement effectively ceases. This may be attributed to the early process of reorientation of particles in the side fill of the pipe and beneath the loading that causes local side fill stiffening so that only a small amount of energy is then lost in the hysteretic response of the system (Faragher et al. 2000). This response may be defined as "plastic shakedown" (Werkmeister et al. 2001). For the unstable condition, with increase in load cycles, the system cannot support the desired load level without plastically deforming. Both VDS and SSS values continue to increase with loading cycles, ultimately reaching excessive values - behavior termed "plastic collapse" by Werkmeister et al. (2001). Similar behavior was 
observed by previous researchers (e.g. Tavakoli Mehrjardi et al. 2012, Hegde and Sitharam 2015a). Fig. 6c and d show the typical stable and unstable behaviors, respectively for the VDS and SSS against number of load cycles. As seen in this figure, for the stable condition the rate of increase in VDS (or SSS) decreases with the number of cycles. It illustrates that, the variations of VDS and SSS become approximately stable within 150 load cycles, and can be expected to reach a fully stabilized condition with relatively few additional cycles of load. In contrast, for unstable conditions, VDS and SSS continue to increase with loading cycles, ultimately realizing a clearly unacceptable deflection after a low, and definite, number of cycles of loading.

\section{Effect of applied repeated load and loading surface diameter (Unreinforced system)}

In order to study the influence of loading surface diameter and amplitude of applied repeated load on the response of buried pipe in unreinforced systems, the tests were performed on pipe embedded at a depth of $1.5 \mathrm{D}$ using various loading surface diameters $(d / D=0.6,0.8,1)$ subjected to repeated loads of 400 and $800 \mathrm{kPa}$. The test configurations and the geometry for buried pipes in unreinforced backfill, with no EPS block, is shown in Fig. 7.

Fig. 7a shows the variations of $V D S$ with number of load cycles, for pipe embedded at depth of $1.5 D$ and for different loading diameters $(d / D=0.6,0.8,1)$ under repeated loading of 400 and $800 \mathrm{kPa}$, respectively. As seen, with increase in loading surface diameter, $V D S$ grows significantly, irrespective of applied pressure. For instance, as shown in Fig. 7a, during the last load cycle under an applied pressure of $400 \mathrm{kPa}$, the VDS values are about $0.20 \%, 0.92 \%$ and $3.6 \%$ for loading plate diameter of 150,200 and $250 \mathrm{~mm}(\mathrm{~d} / \mathrm{D}=0.6,0.8,1)$, respectively. The corresponding values under an applied pressure of $800 \mathrm{kPa}$ are $2.9 \%, 6.84 \%$ and $19.95 \%$.

As seen in Fig. 7a for an applied pressure of $400 \mathrm{kPa}, V D S$ initially increases sharply but soon the increments reduce, leading to an approximately resilient response after about 30 and 75 load cycles for loading surface diameters of $150 \mathrm{~mm}$ and $200 \mathrm{~mm}$, respectively. For the loading surface diameter of $250 \mathrm{~mm}$, stability is anticipated in only a few additional cycles of load, beyond the 150 applied. Based on Fig. 7a for an applied pressure of $400 \mathrm{kPa}$ (simulating non-heavy traffic loading), the loading surface diameter of $250 \mathrm{~mm}(d / D=1)$, as compared to the diameters of 150 and $200 \mathrm{~mm}(d / D=0.6,0.8)$, has the most impact on $V D S$ value $(V D S=3.6 \%)$. Nevertheless, it remains allowable according to AASHTO (2010), in which the upper limit is set at 5\% to avoid snap-through buckling of the pipe. 
However, with increase in the magnitude of the repeated applied pressure to $800 \mathrm{kPa}$, the value of VDS grows greatly (Fig. 7a), where the behavior becomes unstable for the loading plate diameter of $250 \mathrm{~mm}(d / D=1)$. The VDS values under heavy repeated load $(800 \mathrm{kPa})$ are more than six times greater than those under $400 \mathrm{kPa}$, showing how significant is the pressure level. As also seen in Fig. 7, while the value of VDS remains within the allowable strain limit of $5 \%$ for the loading surface diameter of $150 \mathrm{~mm}(d / D=0.6)$, for the larger diameters $V D S$ is greater than $5 \%(d / D=0.8)$ or unstable $(d / D=1)$.

Fig. $7 \mathrm{~b}$ portrays variations of SSS against number of load cycles, for the same loading, pipe and embedment arrangements. Similar to $V D S$ response, for an applied pressure of $400 \mathrm{kPa}$, SSS variation becomes approximately stable (i.e. resilient) within 150 load cycles. Comparing the responses within 150 cycles of 400 $\mathrm{kPa}$ loading, it is also clear that SSS is growing non-linearly with increasing load plate diameter (there is a $\sim 42 \%$ rise in SSS for an increase from 150 to $200 \mathrm{~mm}$ but a $\sim 380 \%$ rise in settlement from 150 to $250 \mathrm{~mm}$ ). For the heavy vehicle load $(800 \mathrm{kPa})$, unstable response is seen for the larger surface diameters of 200 and $250 \mathrm{~mm}$ $(\mathrm{d} / \mathrm{D}=0.8,1)$ and even at $150 \mathrm{~mm}$ diameter, the response is still excessive even if (possibly) stabilizing.

Fig. 7c depicts the variation of pressure acting on the pipe crown versus number of load cycles for these same arrangements. It is found out that for the applied pressure of $400 \mathrm{kPa}$, when the loading plate diameter increases from $150 \mathrm{~mm}$ to $250 \mathrm{~mm}$, at last loading cycle, the pressure on the pipe crown has risen from $46 \mathrm{kPa}$ to $58 \mathrm{kPa}$. The corresponding values for the applied pressure of $800 \mathrm{kPa}$ are 106 and $240 \mathrm{kPa}$ respectively. Thus, the use of greater loading plate diameter has the more impact on the soil-pipe system due to the expansion of the stress zone beneath loading plate and above pipe. The stresses on the pipe crown under heavy repeated load ( 800 $\mathrm{kPa}$ ) are about 2.3, 2.63 and 4.13 times greater, respectively, than those when under $400 \mathrm{kPa}$ for loading surface diameters of 150,200 and $250 \mathrm{~mm}(d / D=0.6,0.8,1)$. Thus, the pressure acting on the pipe crown varies disproportionately with amplitude of load cycle (the pressure grew by a factor of 2.3-4.13 whereas the amplitude of load cycle only doubled). There is also a non-linearity of pipe crown stress with applied force - when the stress at the surface is $400 \mathrm{kPa}$ then there is a small increase in pipe crown stress (about 17.4\%) when the force rises by $77 \%$, but no more (about $6.6 \%$ ) when it rises by $1.77 \%$ (plate diameter increases from 150 to $200 \mathrm{~mm}$ and from 150 to $250 \mathrm{~mm}$ ). Non-linearity, although in the opposite sense, occurs when the plate diameter changes under an applied stress of $800 \mathrm{kPa}$ - now a similar percentage increase is seen when the plate diameter increases from 150 to $200 \mathrm{~mm}$ whereas further increase to $250 \mathrm{~mm}$, cause system collapse. Together, these observations may be interpreted as indicating that there is not a consistent load distribution mechanism at play 
under all loading circumstances. At low loading there appears to be some capacity for load spreading whereas at higher stresses this is not the case, suggesting that local failure (which would be associated with reduced stiffnesses) may have occurred, causing the previous stress distribution patterns to be disrupted.

Overall, the results in Fig. 7 show that for the pipe with diameter of $250 \mathrm{~mm}$ under heavy repeated load of $800 \mathrm{kPa}$, the embedment depth of $1.5 \mathrm{D}$ is not adequate, though it appears marginally adequate under the lower surface stress. In continuation of the tests, therefore, to reach a stable condition for the loading plate diameter of $250 \mathrm{~mm}$, which is recommended by Brito et al. (2009), for simulating heavy traffic load of $800 \mathrm{kPa}$, different solutions such as increase in pipe embedment depth, use of EPS block and geocell layer were examined.

\section{Effect of embedment depth of pipe (Unreinforced system)}

To evaluate the effect of deeper embedment, Fig. 8a compares the variations of maximum VDS with the number of load cycles, for plate loading diameter of $250 \mathrm{~mm}(d / D=1)$ and for pipe embedment depths of $1.5 \mathrm{D}$ and $2 D$ under repeated loading of $800 \mathrm{kPa}$. As seen, the variation of VDS for an embedment depth of 2D reaches a stable condition but, at the last cycle of loading, it is still outside the allowable range at $8.72 \%$ which is clearly unstable for an embedment depth of $1.5 \mathrm{D}$. Therefore, soil reinforcement (in this study, the use of EPS block or geocell reinforcement) is worth investigating in order to reduce the VDS value into an allowable range (less than 5\%).

The variations of maximum SSS for the same arrangements is shown in Fig. 8b. According to this figure, with increasing the embedment depth from $1.5 D$ to $2 D$, SSS gets approximately stable. At a load plate diameter of $250 \mathrm{~mm}(d / D=1)$, the stressed zone for a $1.5 D$ embedment depth intersects the pipe, thus its rigidity is partly responsible for the SSS response. However, the pipe's rigidity will have less effect on SSS with increasing embedment.

Fig. 8c illustrates the variations of maximum pipe crown stress for the same combinations of embedment and load. As for $V D S$ and $S S S$, the increase in embedment depth of pipe from $1.5 D$ to $2 D$ tends to achieve stability. With increase in pipe embedment depth, the pressure transferred to the pipe crown decreases as the stress is distributed elsewhere, and this results in a lower deformation system. 


\section{Effect of EPS block width (Unreinforced system)}

As described in the introduction to this paper, the ultra-lightweight, flexible and energy-absorbing properties of EPS geofoam placed above a pipe can lead to re-distribution of the loading-induced stresses in the ground so that the stress on the pipe crown is reduced. One explanation is that the deformation within the geofoam, due to repeated loading, causes stress to be attracted to the stiffer soil either side of the geofoam so that a 'stress-shadow' occurs under the geofoam - i.e. on the pipe crown (Fig. 5b). To investigate this potential benefit, EPS blocks were placed over pipes embedded at a depth of $2 D$, as shown in Fig. $5 b$.

The variation of maximum VDS, maximum SSS and stress over the pipe crown with number of load cycles for plate loading diameter of $250 \mathrm{~mm}(d / D=1)$, pipe embedment depths of $2 D$ and different widths of EPS block $(D, 1.5 D$ and $2 D$ and $2.5 D)$ under 150 load cycles of repeated loading of $800 \mathrm{kPa}$ is shown in Fig. 9 . The EPS block was fixed at a thickness of $0.6 D\left(h_{e}=0.6 D\right)$ and density of $40 \mathrm{~kg} / \mathrm{m}^{3}$.

Figs. 9b illustrates that, with increase in the width of EPS block, the amount of SSS increases. As seen in this figure, an EPS block does make the SSS behavior worse. e.g. for the EPS block with a width of $2 D$, unstable condition with a large settlement of $88 \mathrm{~mm}$ occurs at load cycle 75 (before reaching load cycle 150). For the EPS block with widths of $D$ and $1.5 D$, excessive settlement could be expected with further loading cycles unless soil permanently bridges over the blocks.

In contrast to the undesirable effect of EPS block on the soil surface settlement (Fig. 9b), Fig. 9a and 9c illustrate the beneficial influence of EPS block inclusion on reduction of VDS of the pipe, plus the soil pressure over the pipe when the backfill was installed with an EPS block. Fig. 9a and 9c respectively reveal that with increase in width of EPS block to 1.5 times the pipe diameter ( $\mathrm{w}=1.5 \mathrm{D}), \mathrm{VDS}$ and pressure on pipe decrease to $5.25 \%$ and $113.2 \mathrm{kPa}$ at the end of load cycle, after which with increase in the width of EPS block, values of $V D S$ and pressure increase. Thus, comparing the results in Fig. 9 shows that the backfill containing EPS block with a width of $1.5 D$ delivers the best performance in $V D S$ and soil pressure reduction over the pipe, so a width of $1.5 \mathrm{D}$ seems appropriate for all experiments. The width of $1.5 \mathrm{D}$ for EPS block, is in line with the studies of Kim et al. (2010) on buried pipe under static loading. They reported no additional improvement in pipe deformation for EPS block widths more than 1.5-2 times the pipe diameter.

\section{Effect of EPS block density (Unreinforced system)}

Fig. 10. illustrates the variation of maximum VDS, maximum SSS and stress over the pipe crown with number of load cycles for plate loading diameter of $250 \mathrm{~mm}(d / D=1)$, pipe embedment depths of $2 D$ and 
different densities of EPS under repeated loading of $800 \mathrm{kPa}$. As seen in this figure, for low EPS density (20 and $30 \mathrm{~kg} / \mathrm{m}^{3}$ ) due to not having enough resistance, punching occurs in the block and large VDS, large SSS and large pipe crown stresses develop at only a few load cycles. Thus, for low EPS densities, geofoam block does not have a positive effect, as pipe rupture results from the high pressures. However, with increase in the density of the EPS to $40 \mathrm{~kg} / \mathrm{m}^{3}$, the $V D S$ and stress on the pipe crown significantly decrease (Fig. 10a and c). The decrease in these two parameters may be attributed to higher energy absorption and higher flexural rigidity of EPS blocks with greater density. According to Fig. 10, although the EPS block inclusion decreases VDS compared with unreinforced backfill, yet at 5.25\% that does not satisfy the recommended limit of 5\% (AASHTO 2010) to avoid snap-through buckling of the pipe. Fig. 10b shows that although the SSS value decreases with EPS density, however its value is more than for the unreinforced cases, irrespective of EPS density. This could be attributed to the compressible nature of the EPS inclusions inside the backfill, over the pipe. However, the SSS values would not satisfy a limit of $30-70 \mathrm{~mm}$ for unsealed low volume roads for surface settlement (ruts) as recommended by AASHTO (1993).

\section{Effect of geocell layer and number of EPS block layers (geocell-reinforced system)}

To investigate the effect of reinforcement on settlement as an alternative to EPS, the results from five tests are compared, all with the pipe embedded at $2 D$ and plate loading diameter of $250 \mathrm{~mm}(d / D=1)$ under repeated loading of $800 \mathrm{kPa}$ :

i. an unreinforced test;

ii. a test containing an EPS block layer of width, $w=1.5 D$, thickness of $75 \mathrm{~mm}\left(h_{e}=0.3 D\right)$, and density of $40 \mathrm{~kg} / \mathrm{m}^{3}$,

iii. a test containing a geocell layer,

iv. a test combining a geocell layer with an EPS block layer of width, $w=1.5 D, 75 \mathrm{~mm}\left(h_{e}=0.3 D\right)$ thick, and density of $40 \mathrm{~kg} / \mathrm{m}^{3}$ (Fig. 5c),

v. a test including a geocell layer and two layers of EPS block having the same width $(\mathrm{w}=1.5 \mathrm{D})$, density of $40 \mathrm{~kg} / \mathrm{m}^{3}$, and thicknesses of 25 and $50 \mathrm{~mm}\left(h_{e l}=0.1 D, h_{e 2}=0.2 D\right)$ (Fig. $\left.5 \mathrm{~d}\right)$. To provide comparable result, 2 layers of EPS block needed to have a total thickness of $0.3 D$ equal to the thickness of one layer of EPS block. Due to difficulty in preparing 2 EPS layers of equal thickness of $37.5 \mathrm{~mm}$ (i.e. $h_{e l}=h_{e 2}=0.15 D$ ), the thicknesses of the layers was selected as $25\left(h_{e l}=0.1 D\right)$ and $50 \mathrm{~mm}\left(h_{e 2}=0.2 D\right)$. 
No data on the best spacing of EPS layers is available although, under static loading with two layers of reinforcement with geofoam, Kim et al. (2010) reported that the space between the two layers should be less than the pipe diameter to be most effective. On this very limited basis, the distance between the geofoam blocks was chosen as $75 \mathrm{~mm}(h=0.3 D)$ in the test reported here (Fig. $5 \mathrm{~d})$.

The variations of the maximum VDS, maximum SSS and maximum stress on the pipe crown with number of load cycles for the five test arrangements are shown in Fig. 11. The figure shows that the geocell reinforcement significantly decreases the VDS and SSS values compared with the unreinforced installation, although the VDS value is still $6.33 \%$ so does not satisfy the limit of 5\% as recommended by AASHTO (2010). To reduce the VDS value to less than 5\% (AASHTO 2010), the combination of geocell layer with one and two layers of EPS shows a VDS value that has reduced to $4.31 \%$ and $3.92 \%$ respectively as the mass and thickness of one layer and two layers of EPS geofoam are the same. Fig. 11b shows that the SSS values for reinforced system including geocell layer with no EPS block, and with one and two layers of EPS block, are respectively about 29.9, 31.53 and $41.16 \mathrm{~mm}$, which satisfy a limit of $30-70 \mathrm{~mm}$ for unsealed low volume roads for surface settlement (ruts) as recommended by AASHTO (1993).

As seen in Fig. 11c, pipe crown stress increases rapidly during initial load cycles regardless of the number of geofoam layers and/or geocell until it becomes sensibly constant. The effect of these layers is to reduce this final stress by $24.7 \%, 53.9 \%$ and $63.1 \%$, relative to the unreinforced system, for the installations reinforced by geocell layer with 0,1 and 2 EPS layers, respectively. The results from pressure cells are in accordance with researches done by Vaslestad et al. (2008), Kim et al. (2010) and Hegde and Sitharam (2015a;b).

With regards to both $V D S$ and pipe crown stress (Fig. 11a and c), one layer of geocell delivers similar benefit to unreinforced system with a single, $75 \mathrm{~mm}$ thick, EPS block although reinforcement is preferred to EPS alone, if SSS is of concern (Fig. 11b). However, the combination of EPS and geocell delivers significant improvement in all aspects monitored. In all the tests there is a bedding-in phase when the soil is compacting and stresses are being redistributed. The authors deduce that a so-called 'shaken-down' state is then reached, with much more effective soil arching being developed in the tests incorporating EPS and reinforcement in combination.

To have a better assessment of the pipe deformation, Fig. 12 illustrates the longitudinal vertical deformation profiles for the different installations at $150^{\text {th }}$ load cycle. Points $1,2,3,4$ and 5 are all located at the 
crown of the pipe at distances of $0,150,300,450$ and $600 \mathrm{~mm}$, respectively, from the mid-point of the pipe's length (where the mid-point is also at the center of loading). As can be seen in Fig. 12, at a distance of $600 \mathrm{~mm}$ from the center of the loaded area, the pipe can be assumed to be unaffected by the loading. Table 4 shows the values of VDS for points 1-5 and for different installations. The results presented in Table 4 again confirm that the geocell-reinforced system considerably improves the pipe behavior compared with the unreinforced system and that this benefit is significantly enhanced by the addition of layers of EPS.

\section{Summary and conclusions}

When HDPE flexible pipes are to be placed in trenches near the ground surface, care is required to ensure that they are not excessively stressed and deformed due to the influence of traffic loads at the surface. Also, the backfilled trench must not settle too much under repeated loading. The results of simulative tests using a sand soil, as reported in this paper, reveal that:

- For fully unreinforced backfill, unacceptably large pipe crown settlements (about $8.72 \%$ of pipe diameter) and stresses can occur under heavy vehicle traffic stresses when the pipe crown is within 2 pipe diameters from the surface.

- For fully unreinforced backfill, settlement and stresses will become unstable (excessively large after a few cycles of loading) when the pipe's depth is reduced to only 1.5 pipe diameters from the surface.

- For the pipe in an unreinforced system, where loading can be guaranteed only to be that of light vehicles (applied stress $\leq 400 \mathrm{kPa}$ ) stable responses can be expected, but pipe crown deflections may still be excessive if the total force is large (e.g. large wheels). However, trench settlements depend far more on the applied stress and not the force. This observation agrees with that predicted by standard stress analysis techniques where stress at depth is largely a function of the total applied force, while stress at the surface is mostly a function of the method of application (i.e. the stress applied) and not of the force.

- $\quad$ Adding EPS above the pipe only helps if the EPS is dense enough to prevent punching $\left(\geq 40 \mathrm{~kg} / \mathrm{m}^{3}\right.$ in the tests performed here), but it's compressibility will tend to make surface settlements worse and, for the tests performed here, the pipe deflection (5.25\% of pipe diameter), though smaller, was still greater than the permissible limit set by the AASHTO (2010) specification. 
- The beneficial performance of a geocell reinforcement on the buried pipe system with and without EPS block was evident. Installation of a single layer of geocell above the pipe placed at a depth of two pipe diameters with no EPS block decreased the VDS, SSS and pressure on the pipe crown, but the VDS value (6.33\% of pipe diameter) still did not satisfy the AASHTO (2010) specification.

- When both EPS and overlying geocell are used, then it is possible to obtain satisfactorily small surface deformations and pipe deflections. It seems that a relatively thin EPS acts to generate arching over the pipe whilst the additional surface deformation that would result is hindered by the reinforcing effect of the geocell. In this case, the combination of geocell layer with one and two layers of EPS shows the pipe deflection value has reduced to $4.31 \%$ and $3.92 \%$, respectively (the mass and thickness of one layer and two layers of EPS geofoam being the same). Also the corresponding values of soil surface settlement (ruts) are respectively about 31.53 and $41.16 \mathrm{~mm}$, which satisfy a limit of 30-70 mm for unsealed low volume roads as recommended by AASHTO (1993).

At present, the findings should be applied cautiously considering the limitations of soil type, dimensions investigated, pipe characteristics, geocell type, etc. In spite of these limitations, the experiments provide insight into the possible combined use of geocell reinforcement and EPS geofoam block in buried pipe applications. They provide an insight into full-scale conditions and could be helpful in designing large-scale buried pipe prototype tests and their simulation by numerical models and methods. Future work could extend that described here to assess other relevant design parameters, such as soil type, loading surface diameter, embedment depth of pipe, EPS block geometric configuration and its characteristics, and stiffness of the geocell material. Also, the economical assessment of EPS blocks, together with geocell layer should be one of the crucial parts of any future project. To generalize the findings, a conceptual model that explains the findings will be needed, along with testing of some of the above, just-mentioned, variants as validating examples, will be required.

\section{Acknowledgments}

The geocell used in this study was provided by DuPont de Nemours Company in UK (the holder of the trademark on the GroundGrid ${ }^{\mathrm{TM}}$ and Typar® products). The authors appreciate all the above support.

\section{References}

AbdelSalam, S. S., Azzam, S. A., and Fakhry, B.M. (2017). "Reliability and 3D Modeling of Flexible Walls with EPS Inclusion.” Int. J. of Geomech.,10.1061/(ASCE)GM.1943-5622.0000853, 04016153. 
Al-Naddaf, M., Han, J., Xu, C., and Rahmaninezhad, S. M. (2019). "Effect of Geofoam on Vertical Stress

Distribution on Buried Structures Subjected to Static and Cyclic Footing Loads.” J. of Pipeline Sys. Eng., 10.1061/(ASCE)PS.1949-1204.0000355.

American Association of State Highway and Transportation Official (AASHTO). (1993). Guide for Design of Pavement Structures, Washington, D.C., USA.

American Association of State Highway and Transportation Official (AASHTO). (2010). LRFD Bridge Design Specifications, Washington, D.C., USA.

Anil, O., Tugrul Erdem, R., and Kantar, E. (2015). "Improving the impact behavior of pipes using geofoam layer for protection." Int. J. Pres. Ves. Pip., 132-133, 52-64.

Arockiasamy, M., Chaallal. O., and Limpeteeparakarn. T. (2006). "Full-scale field tests on flexible pipes under live load application.” J. Perform. Constr. Fac., 10.1061/(ASCE)0887-3828(2006)20:1(21).

ASTM International. (2007). "Standard test method for density and unit weight of soil in place by the sand-cone method." ASTM D1556, West Conshohocken, PA.

ASTM International. (2008). "Standard practice for underground installation of thermoplastic pipe for sewers and other gravity-flow applications.” ASTM D2321, West Conshohocken, PA.

ASTM International. (2009). "Standard Test Method for Repetitive Static Plate Load Tests of Soils and Flexible Pavement Components, for Use in Evaluation and Design of Airport and Highway Pavements.” ASTM, D1195, West Conshohocken, PA.

ASTM International. (2010). "Standard Test Method for Compressive Properties of Rigid Cellular Plastics." ASTM D1621, West Conshohocken, PA.

ASTM International. (2011). "Standard practice for Classification of Soils for Engineering Purposes (Unified Soil Classification System).” ASTM D2487, West Conshohocken, PA.

ASTM International. (2012). "Standard Test Methods for Laboratory Compaction Characteristics of Soil Using Modified Effort.” ASTM D1557, West Conshohocken, PA.

ASTM International. (2015). "Standard specification for unconsolidated-undrained triaxial compression test on cohesive soils." ASTM D2850, West Conshohocken, PA.

Barrett, J. C., and Valsangkar, A. J. (2009). "Effectiveness of connectors in geofoam block construction.” Geotext. Geomembranes, 27(3), 211-216.

Bartlett, S. F., Lingwall, B. N., and Vaslestad, J. (2015). "Methods of protecting buried pipelines and culverts in transportation infrastructure using EPS geofoam.” Geotext. Geomembranes, 43(5), 450-461. 
Beju, Y. Z., and Mandal, J. N. (2017). “Expanded polystyrene (EPS) geofoam: preliminary characteristic evaluation.” Transportation Geotechnics and Geoecology, 189, 239-246.

Brito, L. A. T., Dawson, A. R., and Kolisoja, P. J. (2009). “Analytical Evaluation of Unbound Granular Layers in Regard to Permanent Deformation." Pro., 8th International on the Bearing Capacity of Roads, Railways, and Airfields (BCR2A'09), University of Illinois at Urbana, IL, USA, 187-196.

BSI (British Standard Institute). (2000). “Thermoplastics ancillary fittings of nominal sizes 110 and 160 for below ground gravity drainage and sewerage." BS 4660, London, U.K.

Dash, S. K. (2012). "Effect of Geocell Type on Load-Carrying Mechanisms of Geocell-Reinforced Sand Foundations.” Int. J. Geomech., 12(5), 537-548.

Dash, S. K., Rajagopal, K., and Krishnaswamy, N. R. (2007). "Behavior of geocell reinforced sand beds under strip loading." Can. Geotech. J., 44(7), 905-916.

Duškov, M. (1997). "Materials research on EPS20 and EPS15 under representative conditions in pavement structures." Geotext. Geomembranes, 15(1-3), 147-181.

Elshesheny, A., Mohamed, M., and Sheehan, T. (2019a). "Buried flexible pipes behavior in unreinforced and reinforced soils under cyclic loading." Geosynth. Int. J., 26(12), 184-205.

Elshesheny, A., Mohamed, M., and Sheehan, T. (2019b). "Performance of Buried Rigid Pipes under the Application of Incrementally Increasing Cyclic Loading.” Soil Dyn. Earthq. Eng., 125, 105729.

Faragher, E., Fleming, P. R., and Rogers, C. D. (2000). “Analysis of repeated-load field testing of buried plastic pipes.” J. of Transp. Eng., 10.1061/(ASCE)0733-947X(2000)126:3(271).

Farnsworth, C. B., Bartlett, S. F., Negussey, D., and Stuedlein, A. W. (2008). "Rapid Construction and Settlement Behavior of Embankment Systems on Soft Foundation Soils.” J. Geotech. Geoenviron, 10.1061/(ASCE)1090-0241(2008)134:3(289).

Ghotbi Siabil, S. M. A., Moghaddas Tafreshi, S. N., Dawson, A. R., and Parvizi Omran, M. (2019). "Behavior of expanded polystyrene (EPS) blocks under cyclic pavement foundation loading." Geosynth. International, 26(1), 1-25.

Hatami, K., and Witthoeft, A. F. (2008). "A numerical study on the use of geofoam to increase the external stability of reinforced soil walls." Geosynth. Int., 15(6), 452-470.

Hegde, A., and Sitharam, T. G. (2015a). "Experimental and numerical studies on protection of buried pipelines and underground utilities using geocells.” Geotext. Geomembranes, 43(5), 372-381. 
Hegde, A., and Sitharam, T. G. (2015b). "Joint Strength and Wall Deformation Characteristics of a Single-

Cell Geocell Subjected to Uniaxial Compression.” Int. J. Geomech., 15(5), 171-181.

Horvath, J. S. (1994). “Expanded Polystyrene (EPS) Geofoam: An Introduction to Material Behavior.” Geotext. Geomembranes, 13 (4), 263-280.

Horvath, J. S. (2010). “Emerging Trends in Failures Involving EPS-Block Geofoam Fills.” J. Perform. Constr. Fac., 10.1061/(ASCE)CF.1943-5509.0000114, 365-372.

Indraratna, B., Biabani, M.M., and Nimbalkar, S. (2015). "Behavior of Geocell-Reinforced Subballast Subjected to Cyclic Loading in Plane-Strain Condition.” J. Geotech. Geoenviron., 10.1061/(ASCE)GT.19435606.0001199.

Kang, J., Parker, F., and Yoo, C. H. (2008a). "Soil-structure interaction for deeply buried corrugated steel pipes. Part I: Embankment installation.” Eng. Struct., 30 (2), 384-392.

Kang, J., Parker, F., and Yoo, C. H. (2008b). "Soil-structure interaction for deeply buried corrugated steel pipes. Part II: Embankment installation.” Eng. Struct., 30(3), 588-594.

Khalaj, O., Darabi, N. J., Tafreshi, S. M., and Mašek, B. (2017). "Protection of Buried Pipe under Repeated Loading by Geocell Reinforcement.” IOP Conference Series: Earth and Environmental Science, UK, Vol. 95(2), 022030.

Kim, H., Choi, B., and Kim, J. (2010). "Reduction of earth pressure on buried pipes by EPS geofoam inclusions." Geotech. Test. J., 33(4), 1-10.

Kou, Y., Shukla, S. K., and Mohyeddin, A. (2018). "Experimental investigation for pressure distribution on flexible conduit covered with sandy soil reinforced with geotextile reinforcement of varying widths." Tunn. Undergr. Sp. Tech., 80,151-163.

Leshchinsky, B., and Ling, H. I. (2012). "Effects of geocell confinement on strength and deformation behavior of gravel." J. of Geotec. and Geoenviron. Eng., 10.1061/(ASCE)GT.1943-5606.0000757.

Leshchinsky, B., and Ling, H. I. (2013). "Numerical modeling of behavior of railway ballasted structure with geocell confinement." Geotext. Geomembranes, 36, 33-43.

Madhavi Latha, G. M., Dash, S. K., and Rajagopal, K. (2009). "Numerical Simulation of the Behavior of Geocell Reinforced Sand in Foundations.” Int. J. of Geomech., 10.1061/(ASCE)15323641(2009)9:4(143).

Madhavi Latha, G. M., and Rajagopal, K. (2007). "Parametric finite element analyses of geocell supported embankments." Can. Geotech. J., 44(8), 917-927. 
Mamatha, K. H., and Dinesh, S. V. (2019). "Performance evaluation of geocell-reinforced pavements." Int. J. Geotech. Eng., 13(3), 277-286.

McAfee, R. P., and Valsangkar, A. J. (2004). “Geotechnical properties of compressible materials used for induced trench construction." J. Test. Eval., 32(2), 143-152.

Meguid, M. A., Ahmed, M. R., Hussein, M. G., and Omeman, Z. (2017a). "Earth Pressure Distribution on a Rigid Box Covered with U-Shaped Geofoam Wrap.” Int. J. Geosynth. and Ground Eng., 3(2), p.11.

Meguid, M. A., and Hussein, M. G. (2017). “A numerical procedure for the assessment of contact pressures on buried structures overlain by EPS geofoam inclusion.” Int. J. of Geosynthetics and Ground Engineering, 3(1), p.2.

Meguid, M. A., Hussein, M. G., Ahmed, M. R., Omeman, Z., and Whalen, J. (2017b). "Investigation of soilgeosynthetic-structure interaction associated with induced trench installation." Geotext. Geomembranes, 45(4), 320-330.

Moghaddas Tafreshi, S. N., and Khalaj, O. (2008). "Laboratory tests of small-diameter HDPE pipes buried in reinforced sand under repeated-load.” Geotext. Geomembranes, 26(2), 145-163.

Moghaddas Tafreshi, S. N., Khalaj, O., and Dawson, A. R. (2014). "Repeated loading of soil containing granulated rubber and multiple geocell layers." Geotext. Geomembranes, 42 (1), 25-38.

Moghaddas Tafreshi, S. N., Sharifi, P., and Dawson, A. R. (2016). "Performance of circular footings on sand by use of multiple-geocell or-planar geotextile reinforcing layers.” Soils Found., 56 (6), 984-997.

Moghaddas Tafreshi, S. N., and Tavakoli Mehrjardi, G. H. (2008). "The Use of Neural Network to Predict the Behavior of Small Plastic Pipes Embedded in Reinforced Sand and Surface Settlement under RepeatedLoad.” Eng. Appl. Artif. Intel., 21 (6), 883-894.

Moghaddas Tafreshi, S. N., Tavakoli Mehrjardi, G. H., and Dawson, A. R. (2012). "Buried pipes in rubber-soil backfilled trenches under cyclic loading.” J. Geotech. Geoenviron. Eng, 10.1061/(ASCE)GT.19435606.0000710 .

Newman, M. P., Bartlett, S. F., and Lawton, E. C. (2010). "Numerical Modeling of Geofoam Embankments.” J. Geotech. Geoenviron. Eng.,10.1061/(ASCE)GT.1943-5606.0000203.

Saarilahti, M. (2002). "Modelling of the wheel and tire.” PhD Thesis, University of Helsinki, Department of Forest Resource Management.

Satyal, S. R., Leshchinsky, B., Han, J., and Neupane, M. (2018). "Use of cellular confinement for improved railway performance on soft subgrades." Geotext. Geomembranes, 46(2), 190-205. 
Spangler, M. G. (1941). “The structural design of flexible pipe culverts.” Bull.31, Iowa Eng. Experiment Station, Iowa State College, Ames, Iowa.

Srivastava, A., Goyal, C. R., and Raghuvanshi, A. (2013). “Load Settlement Response of Footing Placed over Buried Flexible Pipe through a Model Plate Load Test.” Int. J. Geomech, 10.1061/(ASCE)GM.19435622.0000228 .

Stark, T. D., Arellano, D., Horvath, J. S., and Leshchinsky, D. (2004). NCHRP Report 529: Guideline and Recommended Standard for Geofoam Applications in Highway Embankments. Transportation Research Board, Washington, D.C.

Talesnick, M. L., Xia, H. W., and Moore, I. D. (2011). "Earth pressure measurements on buried HDPE pipe." Géotechnique, 61(9), 721-732.

Tavakoli Mehrjardi, G. H., Behrad, R., and Moghaddas Tafreshi, S. N., (2019). "Scale effect on the behavior of geocell-reinforced soil.” Geotext. Geomembranes, 47(2), 154-163.

Tavakoli Mehrjardi, G. H., Moghaddas Tafreshi, S. N., and Dawson, A. R., (2012). "Combined use of geocell reinforcement and rubber-soil mixtures to improve performance of buried pipes." Geotext. Geomembranes, 34(1), 116-130.

Tavakoli Mehrjardi, G. H., MoghaddasTafreshi, S. N., and Dawson, A. R, (2015). "Numerical analysis on Buried pipes protected by combination of geocell reinforcement and rubber-soil mixture.” Int. J. of Civ. Eng., 13(2), 91-104.

Thakur, J. k., Han, J., Pokharel, S. K., and Parsons, R. L. (2012). "Performance of geocell-reinforced recycled asphalt pavement (RAP) bases over weak subgrade under cyclic plate loading." Geotext. Geomembranes, $35,14-24$.

Tingle, J. S., and Jersey, S. R. (2007). "Empirical design methods for geosynthetic-reinforced low-volume roads.” Transport. Res. Rec., 1989-2(1), 91-101.

Trung Ngo. N., Indraratna, B., Rujikiatkamjorn, C., and Biabani, M. M. (2016). "Experimental and Discrete Element Modeling of Geocell-Stabilized Subballast Subjected to Cyclic Loading.” J. Geotech. Geoenviro. Eng., 142(4).

Vaslestad, J., Johansen, T. H., and Holm, W. (1993). "Load reduction on rigid culverts beneath high fills: longterm behavior." Transport. Res. Rec., 1415, 58-68. 
Vaslestad, J., Sayd, M. S., Johanson, T. H., and Wiman, L. (2008). "Load reduction and arching on buried rigid culverts using EPS Geofoam. Design method and instrumented field tests.” Proc., Nordic Geotetecnical Meeting $n r$ 15, Sandefjord, Norway.

Werkmeister, S., Dawson, A., and Wellner, F. (2001). "Permanent deformation behavior of granular materials and the shakedown concept." Transport. Res. Rec., 1757(1), 75-81.

Witthoeft, A., and Kim, H. (2015). "Numerical investigation of earth pressure reduction on buried pipes using EPS geofoam compressible inclusions." Geosynth. Int., 23(4): 1-14.

Zarnani, S., and Bathurst, R. J. (2007). "Experimental investigation of EPS geofoam seismic buffers using shaking table tests." Geosynth. Int., 14(3), 165-177.

Zou, Y., Small, J. C., and Leo, C. J. (2000). "Behavior of EPS Geofoam as Flexible Pavement Subgrade Material in Model Tests.” Geosynth. Int., 7(1), 1-22.

\begin{tabular}{|ll|}
\hline Nomenclature \\
$G_{s}$ & Specific gravity \\
$\phi$ & Soil angle of internal friction \\
$c$ & Soil cohesion \\
$h_{g}$ & Height of geocell \\
$D$ & Pipe diameter \\
$b$ & Width of geocell layer \\
$u$ & Embedded depth of geocell layer below the loading surface \\
$\mathrm{h}_{\mathrm{e}}$ & Thickness of EPS block \\
$\mathrm{w}$ & Width of EPS block \\
$d$ & Diameter of loading surface \\
$\mathrm{h}$ & Space of two EPS block \\
$Z$ & Embedment depth of pipe \\
$\mathrm{VDS}$ & Vertical diameter strain \\
SSS & Soil surface settlement \\
$H D P E$ & High Density Polyethylene \\
\hline
\end{tabular}

\section{List of Tables}

\begin{tabular}{|l|l|}
\hline Table 1 & Physical and mechanical properties of EPS geofoam \\
\hline Table 2 & The engineering characteristics of base geotextile component of geocell \\
\hline Table 3 & Testing program and summary of the tests \\
\hline Table 4 & $\begin{array}{l}\text { VDS values for points } 1,2,3,4 \text { and } 5 \text { at the crown of the pipe and located, respectively at } \\
\text { distances of zero, 150, 300, 450 and } 600 \mathrm{~mm} \text { from the mid-point of the pipe's length, for } \\
\text { different installations }\end{array}$ \\
\hline
\end{tabular}




\begin{tabular}{|c|c|c|c|}
\hline \multicolumn{4}{|c|}{$\begin{array}{l}\text { Table } 1 . \\
\text { Physical and mechanical properties of EPS geofoam }\end{array}$} \\
\hline \multirow{2}{*}{ Engineering properties } & \multicolumn{3}{|c|}{ Value for } \\
\hline & EPS 20 & EPS 30 & EPS 40 \\
\hline Measured density $\left(\mathrm{kg} / \mathrm{m}^{3}\right)$ & $17 \sim 19$ & $27 \sim 29$ & $37 \sim 39$ \\
\hline Angle of internal friction $\left({ }^{\circ}\right)$ & 2.20 & 3.15 & 3.55 \\
\hline Apparent cohesion (kPa) & 40.40 & 70.35 & 95.30 \\
\hline Elastic modulus - $1 \%$ strain $(\mathrm{MPa})$ & 0.81 & 2.16 & 2.86 \\
\hline Compressive strength $-10 \%$ strain $(\mathrm{kPa})$ & 83.67 & 156.4 & 244.14 \\
\hline
\end{tabular}

\begin{tabular}{|c|c|}
\hline Property & Value \\
\hline Type of geotextile & Non-woven \\
\hline Material & Polypropylene \\
\hline Mass per unit area $\left(\mathrm{g} / \mathrm{m}^{2}\right)$ & 190 \\
\hline Thickness under $2 \mathrm{kN} / \mathrm{m}^{2}(\mathrm{~mm})$ & 0.57 \\
\hline Thickness under $200 \mathrm{kN} / \mathrm{m}^{2}(\mathrm{~mm})$ & 0.47 \\
\hline Tensile strength $(\mathrm{kN} / \mathrm{m})$ & 13.1 \\
\hline Strength at $5 \%(\mathrm{kN} / \mathrm{m})$ & 5.7 \\
\hline Effective opening size $(\mathrm{mm})$ & 0.08 \\
\hline Height of cells, $\mathrm{h}_{\mathrm{g}}(\mathrm{mm})$ & 100 \\
\hline Geocell pocket size (width and length of cell) (mm) & 110 \\
\hline
\end{tabular}


Table 3.

Testing program and summary of the tests

\begin{tabular}{|c|c|c|c|c|c|c|c|c|c|}
\hline Test & $\begin{array}{c}\text { Reinforcement } \\
\text { Status }\end{array}$ & $\begin{array}{c}\text { Plate } \\
\text { Diameter } \\
(d)\end{array}$ & $\begin{array}{l}\text { Amplitu } \\
\text { de of } \\
\text { repeated } \\
\text { load } \\
\text { (kPa) }\end{array}$ & $\begin{array}{c}\text { Buried } \\
\text { pipe } \\
\text { depth }(Z)\end{array}$ & $\begin{array}{c}\text { Total } \\
\text { thickn } \\
\text { ess of } \\
\text { EPS } \\
\text { Block } \\
\left(h_{e}\right)\end{array}$ & $\begin{array}{l}\text { Width of } \\
\text { EPS Block } \\
\quad(w)\end{array}$ & $\begin{array}{c}\text { EPS } \\
\text { Density } \\
\left(\mathbf{k g} / \mathbf{m}^{3}\right)\end{array}$ & $\begin{array}{c}\text { No. of } \\
\text { EPS } \\
\text { layer (s) }\end{array}$ & No. of Tests \\
\hline \multirow{3}{*}{$\begin{array}{c}\text { No } \\
\text { EPS } \\
\text { Block }\end{array}$} & Unreinforced & $\begin{array}{c}0.6 \mathrm{D} \\
0.8 \mathrm{D} \\
\mathrm{D}\end{array}$ & $\begin{array}{l}400 \\
800\end{array}$ & $1.5 \mathrm{D}$ & --- & --- & --- & --- & $6+3 *$ \\
\hline & Unreinforced & \multirow[b]{2}{*}{$\mathrm{D}$} & \multirow[b]{2}{*}{800} & \multirow[b]{2}{*}{$2 \mathrm{D}$} & \multirow[b]{2}{*}{---} & \multirow[b]{2}{*}{---} & \multirow[b]{2}{*}{---} & \multirow[b]{2}{*}{---} & \multirow[b]{2}{*}{$2+2 *$} \\
\hline & $\begin{array}{c}\text { Geocell } \\
\text { Reinforced }\end{array}$ & & & & & & & & \\
\hline \multirow{4}{*}{$\begin{array}{l}\text { EPS } \\
\text { Block }\end{array}$} & \multirow[t]{2}{*}{ Unreinforced } & \multirow{4}{*}{$\mathrm{D}$} & \multirow{4}{*}{800} & \multirow{4}{*}{$2 \mathrm{D}$} & \multirow[t]{2}{*}{$0.6 \mathrm{D}$} & $1.5 \mathrm{D}$ & $\begin{array}{c}20,30 \\
40\end{array}$ & \multirow[t]{2}{*}{1} & $3+1 *$ \\
\hline & & & & & & 1D, 2D & 40 & & $2+1 *$ \\
\hline & Unreinforced & & & & \multirow{2}{*}{$0.3 \mathrm{D}$} & \multirow{2}{*}{$1.5 \mathrm{D}$} & \multirow[b]{2}{*}{40} & 1 & $1+1 *$ \\
\hline & $\begin{array}{c}\text { Geocell } \\
\text { Reinforced }\end{array}$ & & & & & & & $1,2 * *$ & $2+2 *$ \\
\hline
\end{tabular}

*The tests which were performed two or three times to verify the repeatability of the test data.

For example, in unreinforced tests on a pipe with an embedment depth of 1.5D, 9 tests were performed, 6 independent tests plus 3 replicates.

$* *$ Two layers of EPS block with thicknesses of 25 and $50 \mathrm{~mm}\left(h_{e 1}=0.1 \mathrm{D}, h_{e 2}=0.2 \mathrm{D}\right)$ and distance of $75 \mathrm{~mm}$ $(h=0.3 D)($ Fig. 5d).

\section{Table 4.}

VDS values for points 1, 2, 3, 4 and 5 at the crown of the pipe and located, respectively at distances of zero, 150, 300, 450 and $600 \mathrm{~mm}$ from the mid-point of the pipe's length, for installations of unreinforced and geocell reinforced backfill with 2 layers of EPS block

\begin{tabular}{|l|c|c|c|c|c|}
\hline \multirow{2}{*}{ Test Condition } & \multicolumn{5}{|c|}{ Point Number and VDS value (\%) } \\
\cline { 2 - 6 } & $\mathbf{1}$ & $\mathbf{2}$ & $\mathbf{3}$ & $\mathbf{4}$ & $\mathbf{5}$ \\
\hline Unrein. (No EPS) & 8.71 & 6.52 & 3.89 & 1.63 & 0.23 \\
\hline Geocell (2 Layers EPS) & 3.92 & 3.28 & 1.85 & 0.85 & 0.01 \\
\hline
\end{tabular}


Fig. 1. Grain size distribution curves for backfill soil (ASTM D 2487)

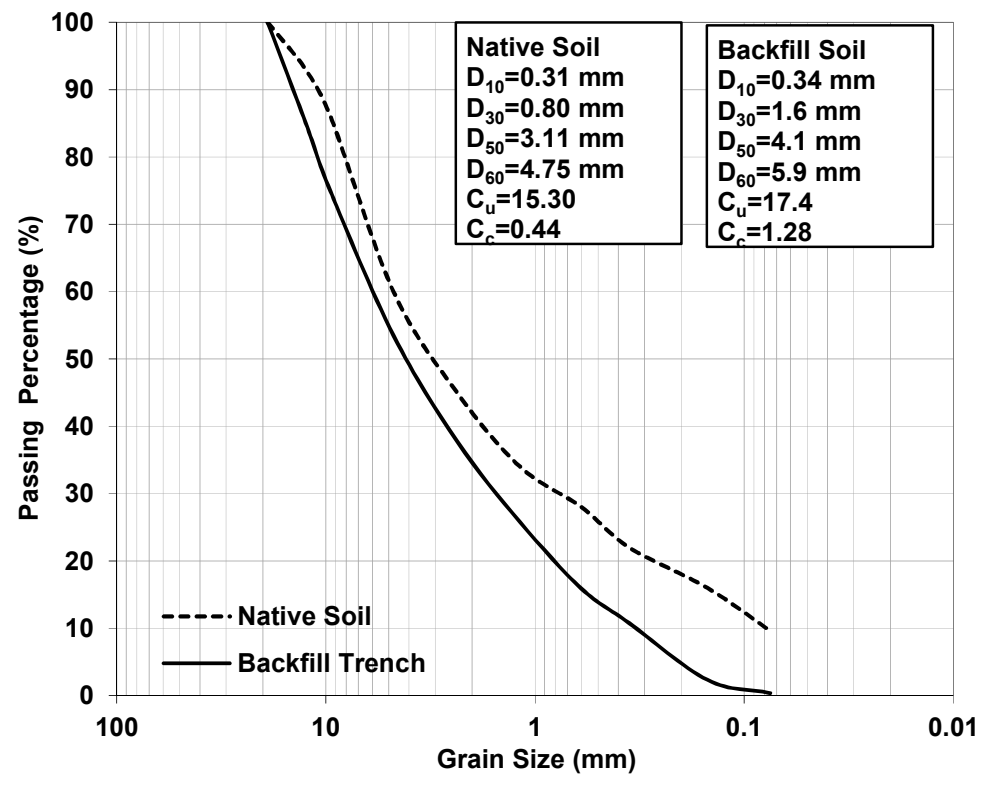


Fig. 2. Schematic view of test setup, instrumentation positions and geometric parameters (unit in $\mathrm{mm}$ )

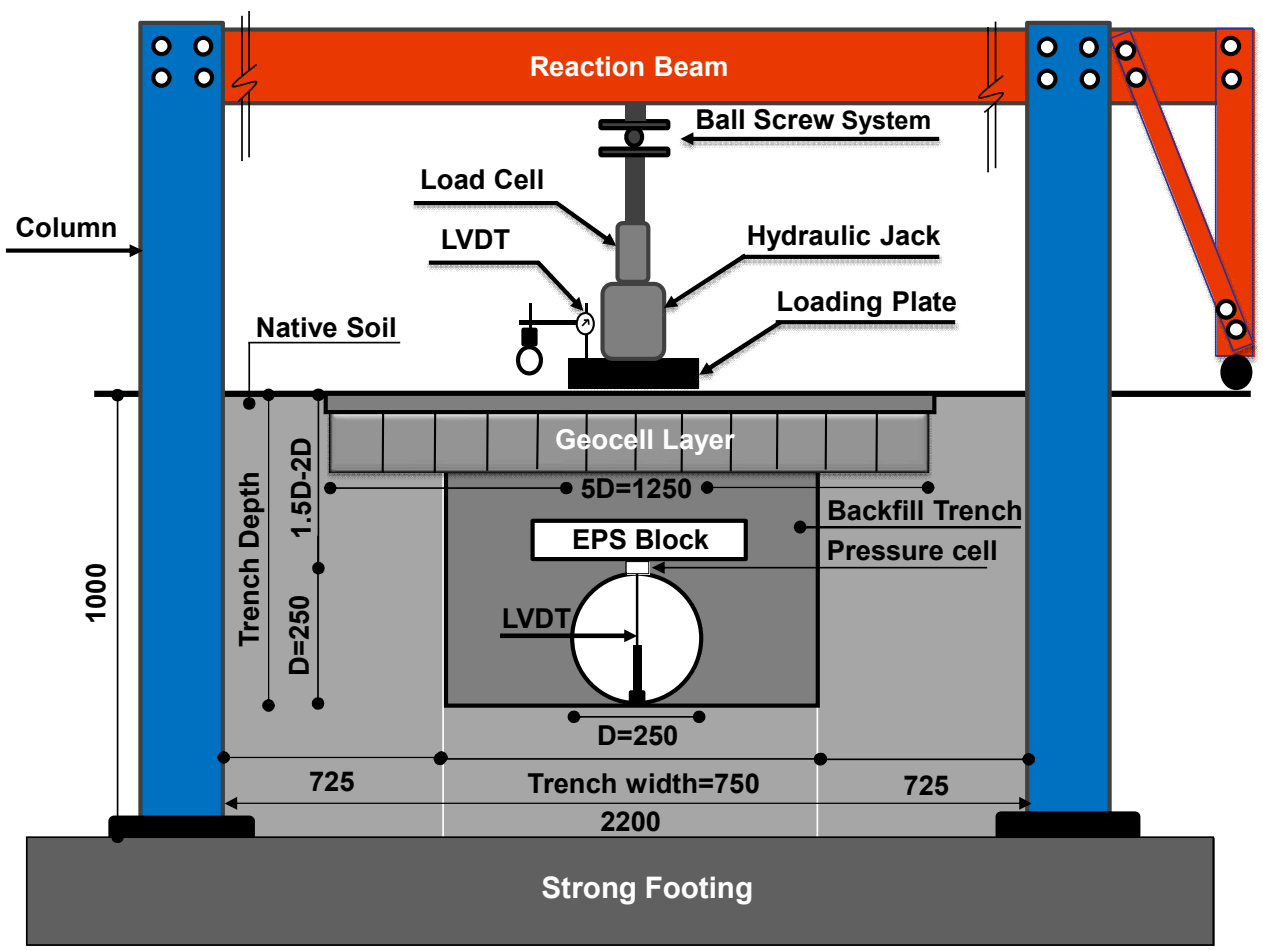



Fig. 3. (a) Schematic installation of LVDTs inside the pipe and
pressure cell on the crown of pipe (unit in $\mathrm{mm}$ ) (b) Photograph
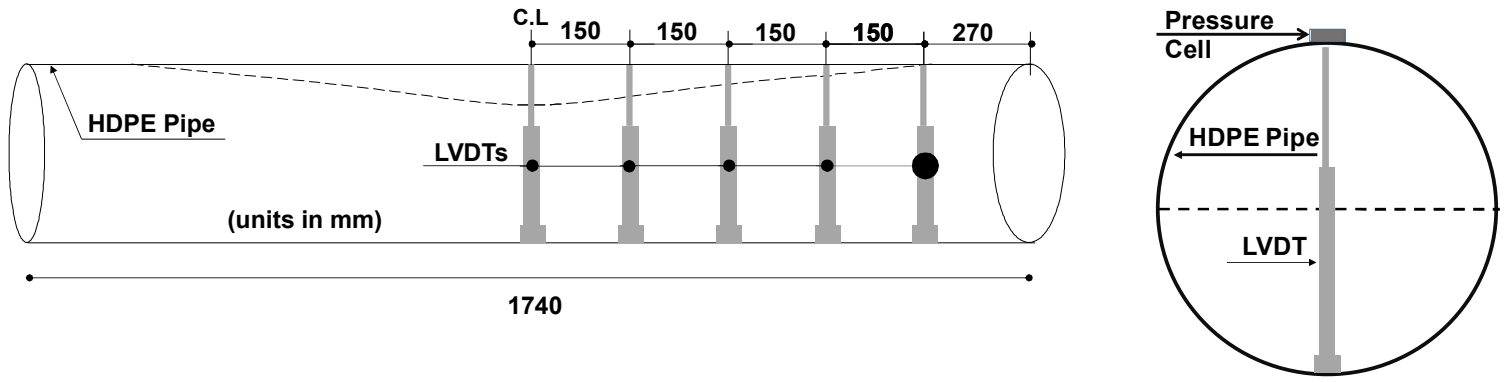

(a)

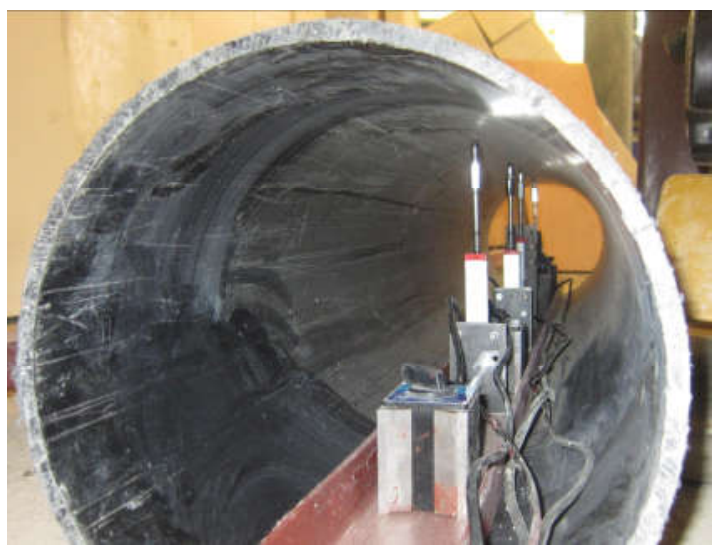

(b) 
Fig. 4. Photograph of (a) pipe installation in trench (b) EPS block
installation over the pipe (c) geocell layer used in experiments,

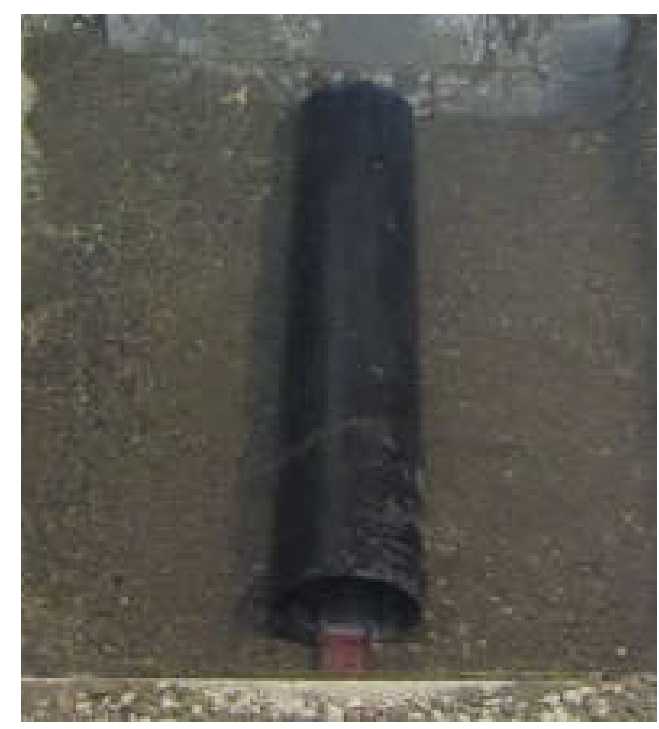

(a)

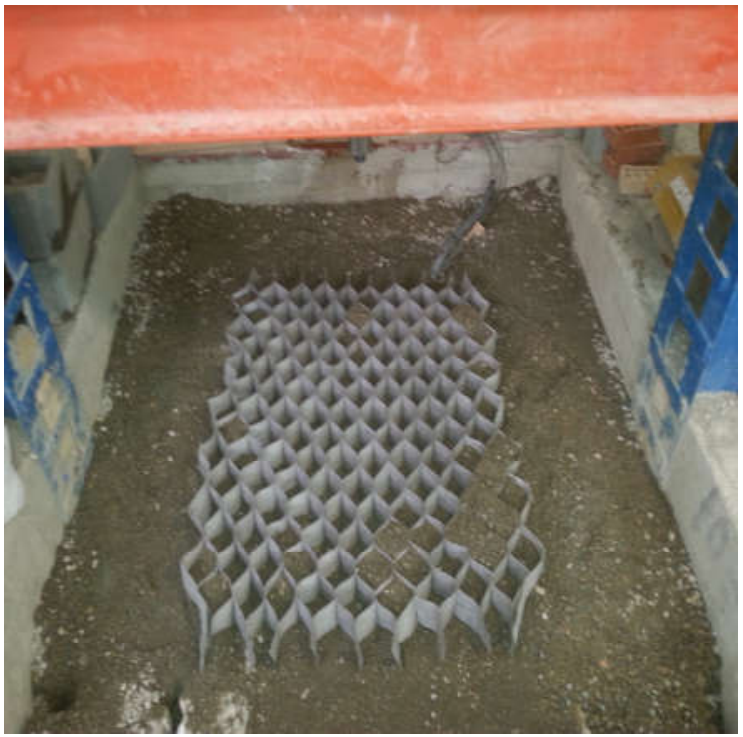

(c)

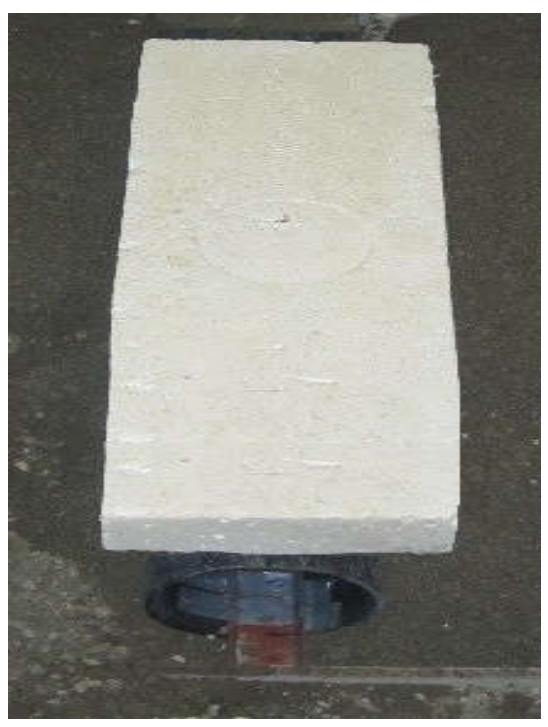

(b)

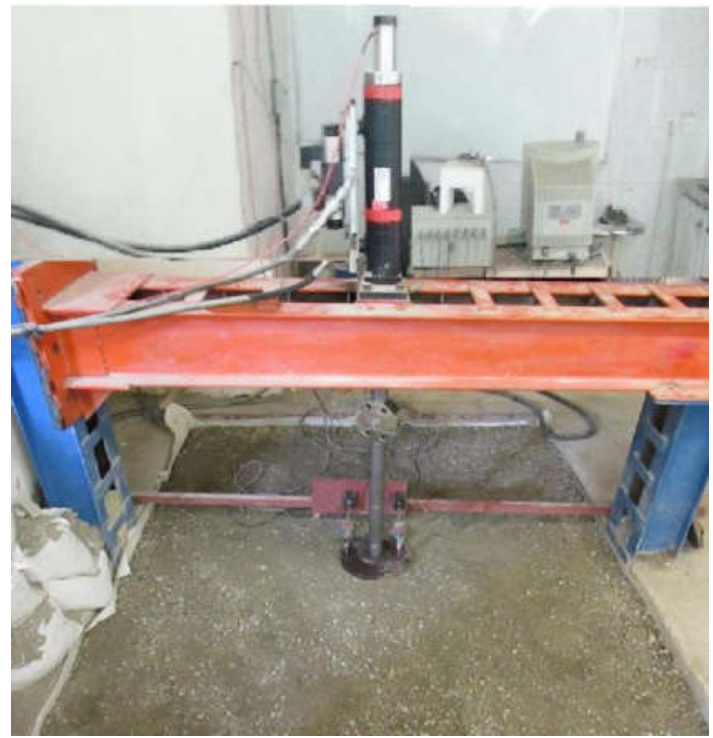

(d) 
Fig. 5. Schematic view of (a) unreinforced backfill without EPS block, (b) unreinforced backfill with EPS block, (c) geocell

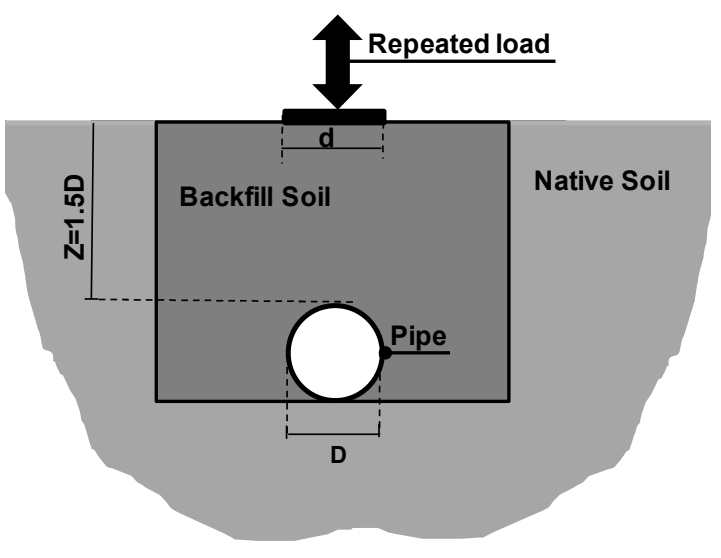

(a)

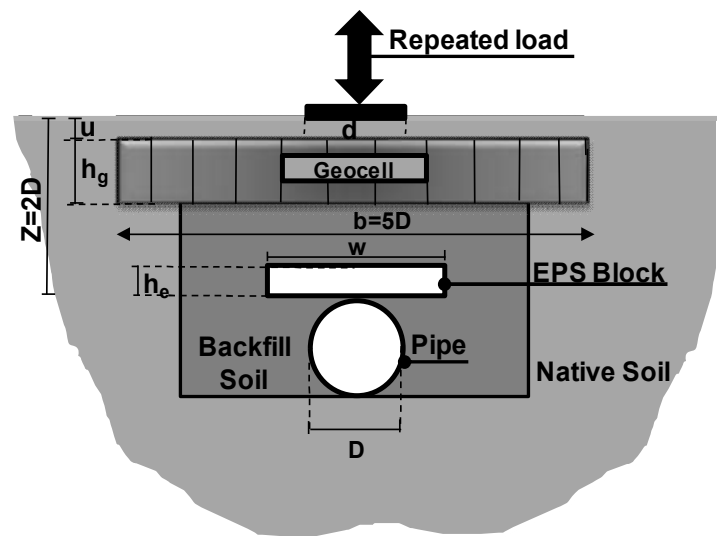

(c)

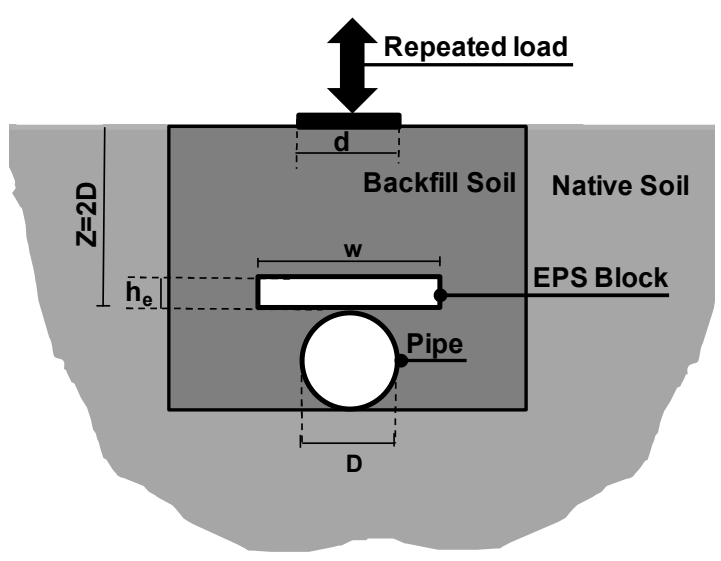

(b)

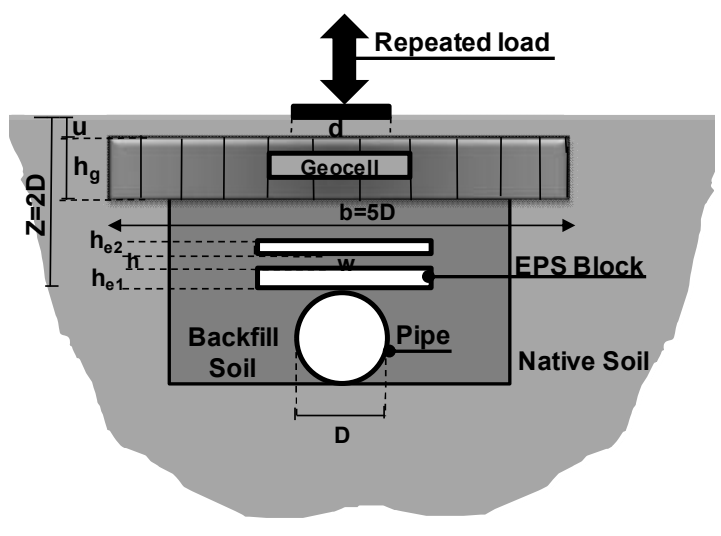

(d) 
Fig. 6. Typical trend of (a) hysteresis curve of VDS, (b) hysteresis curve of SSS, (c) VDS with load cycles, (d) SSS with load cycles

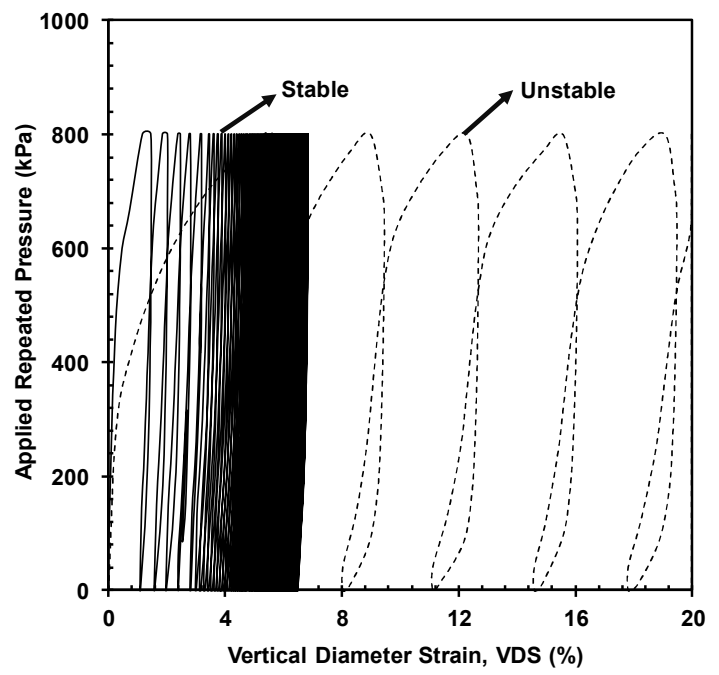

(a)

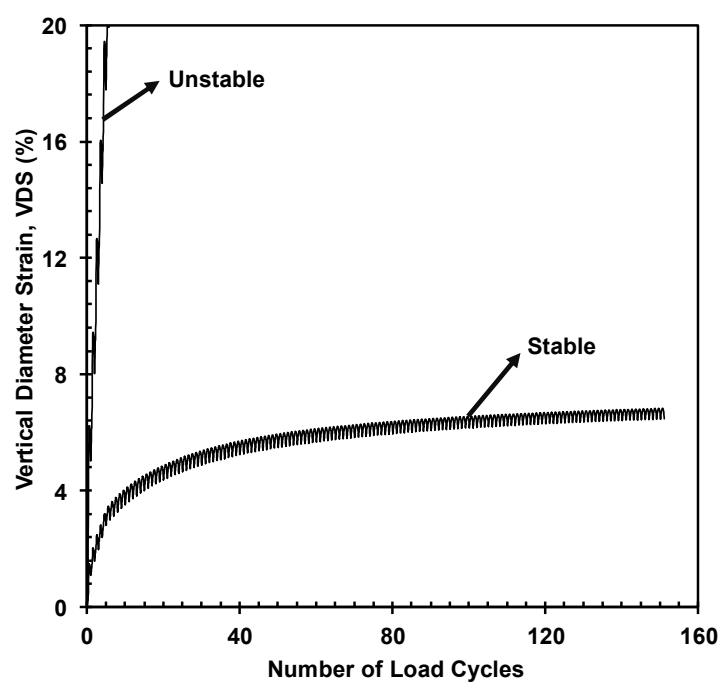

(c)

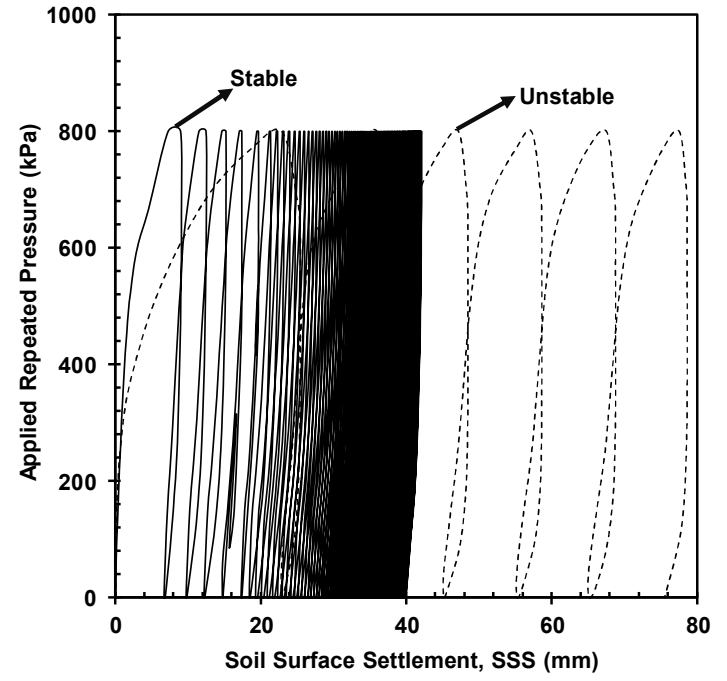

(b)

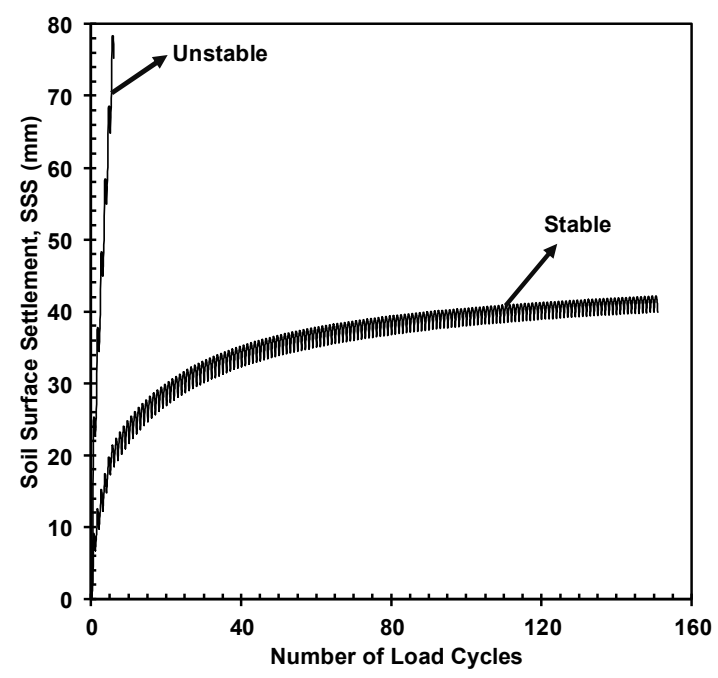

(d) 
Fig. 7. The effect of load plate diameter and amplitude of applied repeated load on (a) maximum values of VDS, (b) maximum

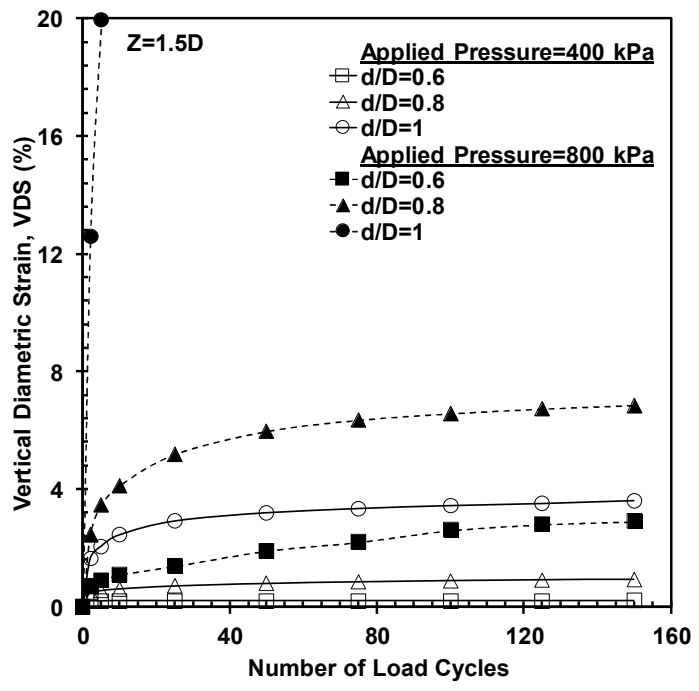

(a)

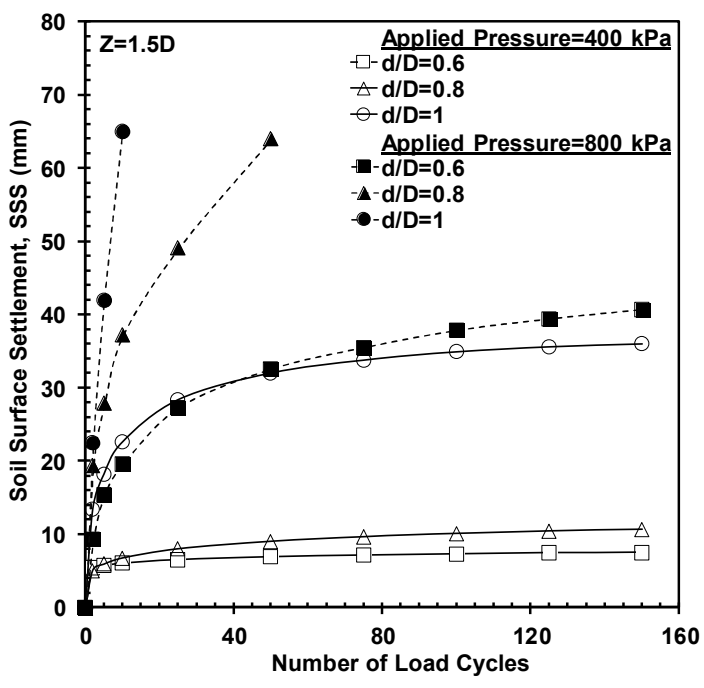

(b)

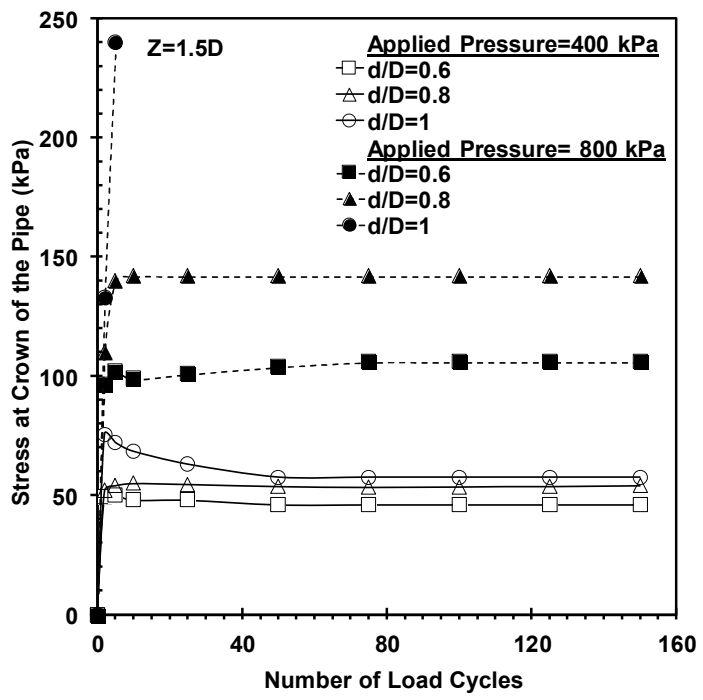

(c) 
Fig. 8. The effect of embedment depth of pipe (1.5D and 2D) on maximum values of VDS and SSS and pressure on crown under



(a)

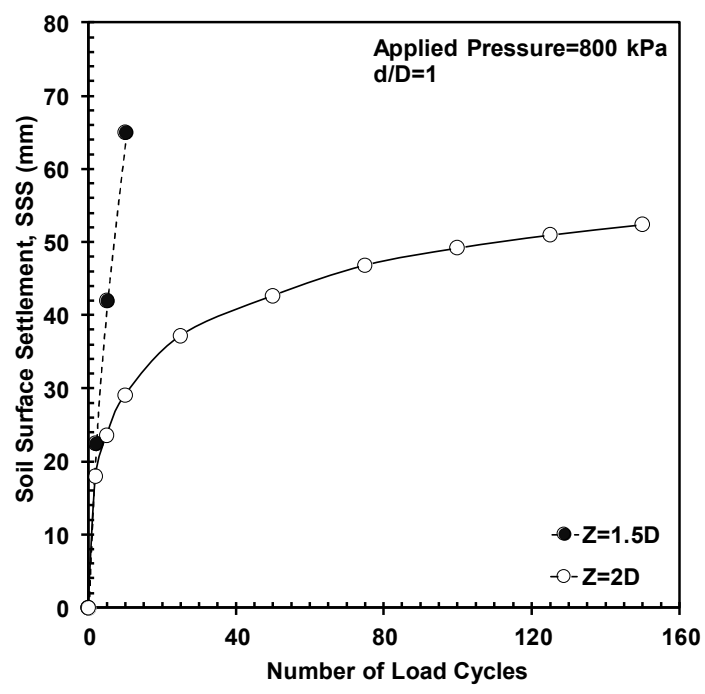

(b)

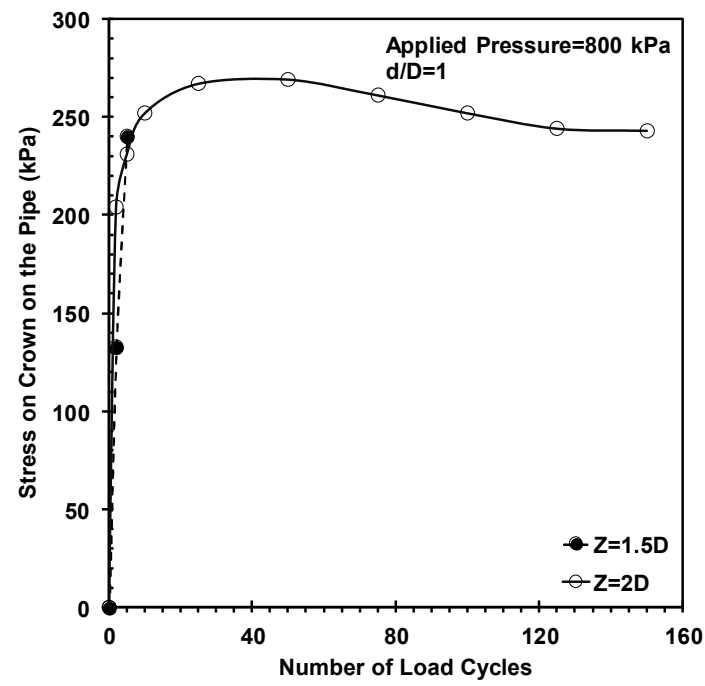

(c) 
Fig. 9. The effect of EPS block width [repeated pressure of 800 $\mathrm{kPa}$; loading surface diameter of $250 \mathrm{~mm}(\mathrm{~d} / \mathrm{D}=1)]$ on (a)

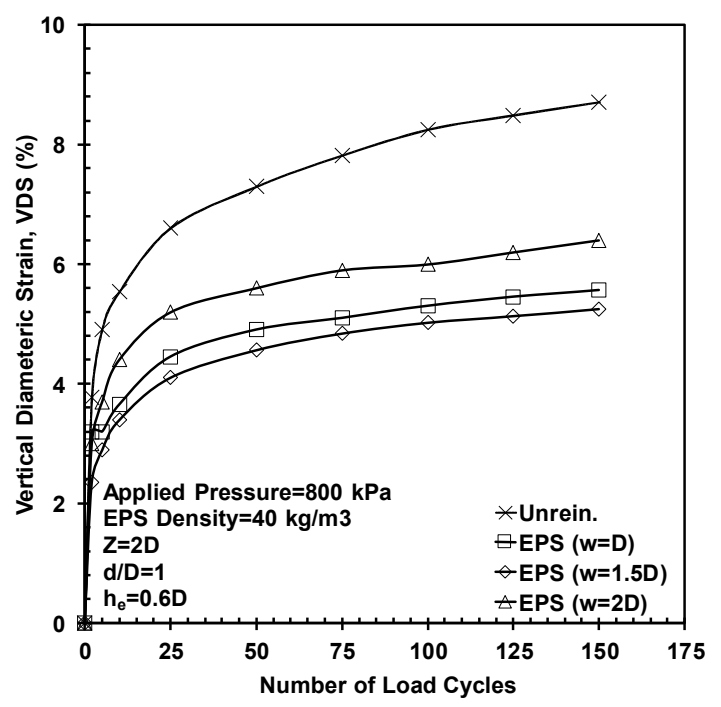

(a)

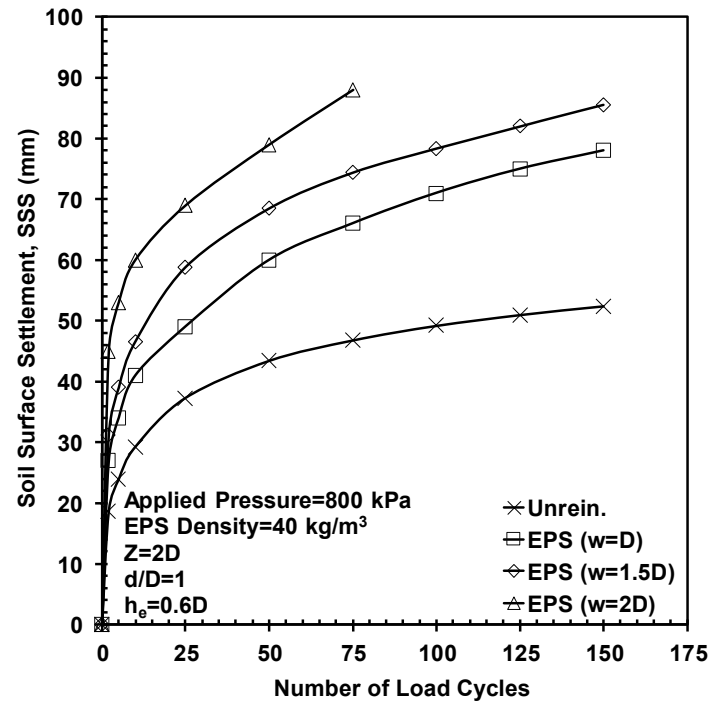

(b)

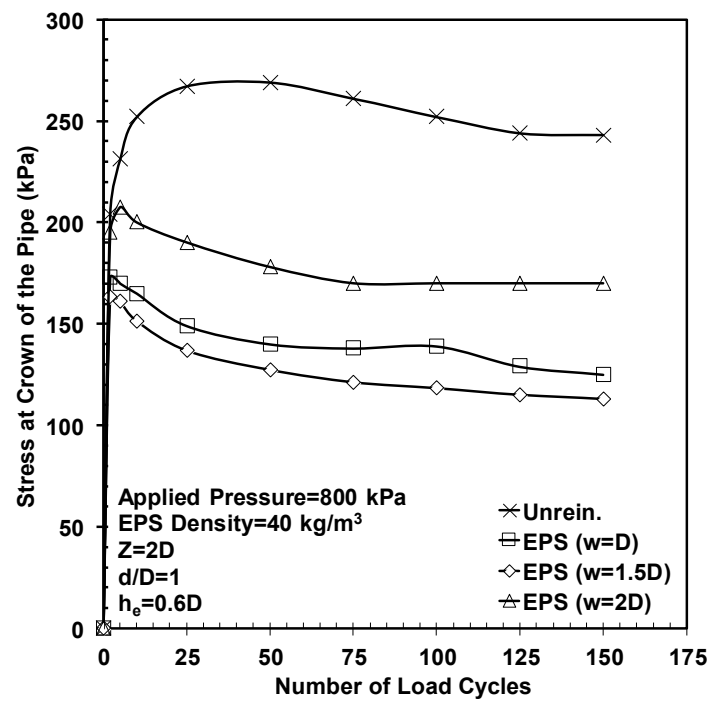

(c) 
Fig. 10. The effect of EPS block density for an installation subjected to a repeated pressure of $800 \mathrm{kPa}$ applied on a loading

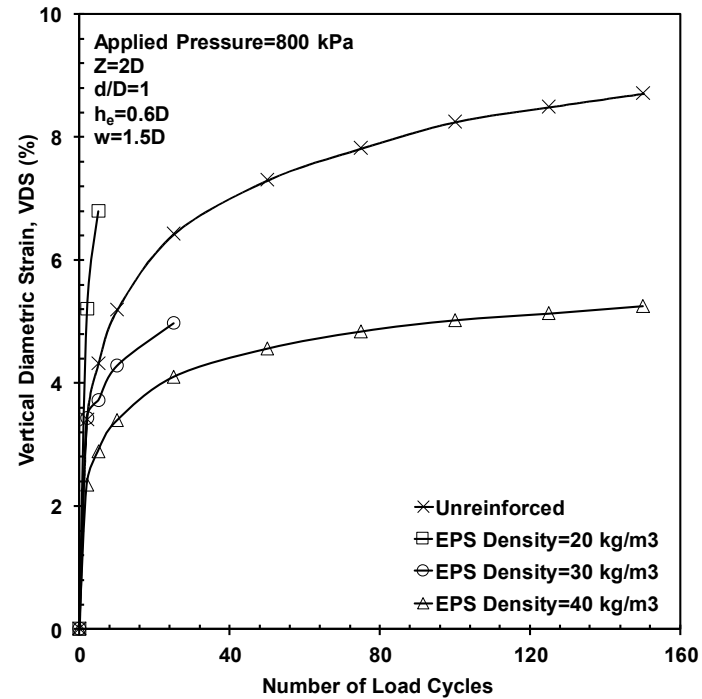

(a)

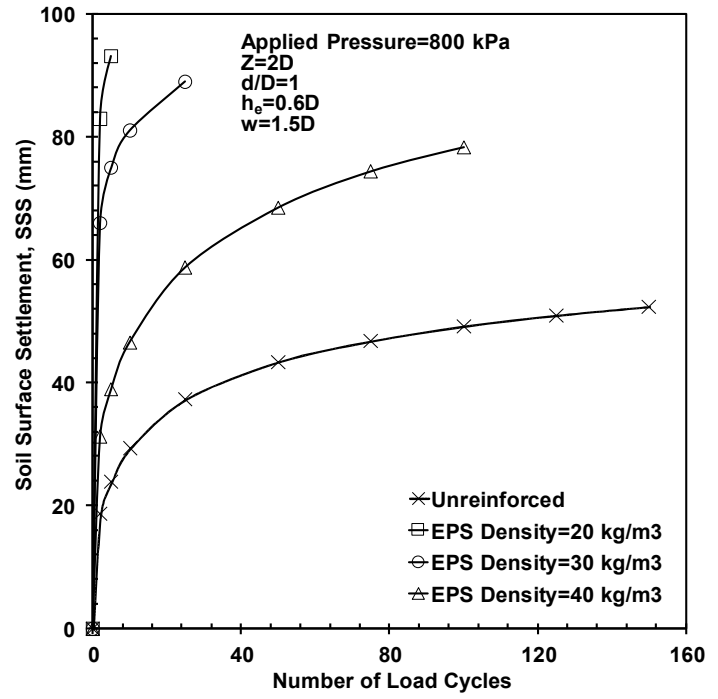

(b)

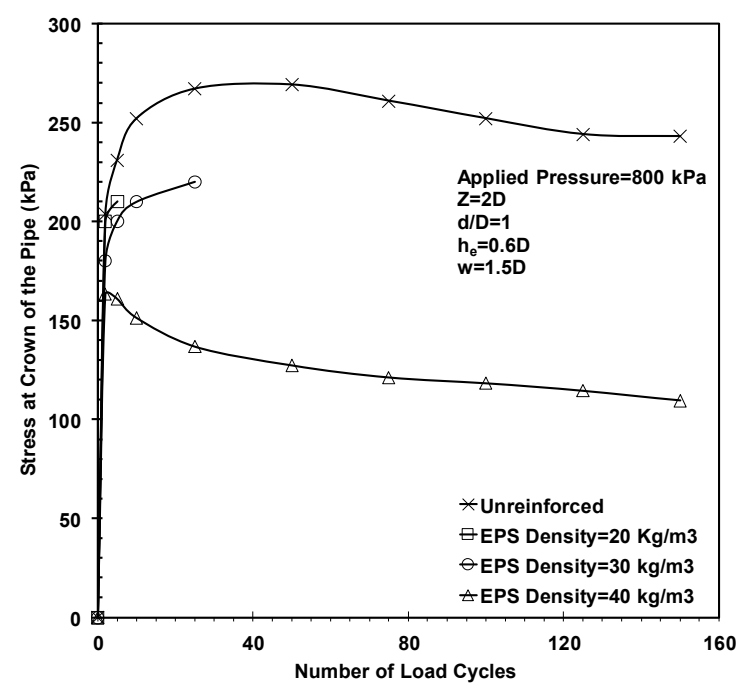

(c) 
Fig. 11. Variation of maximum values of VDS and SSS and pressure on crown with number of load cycles, for different

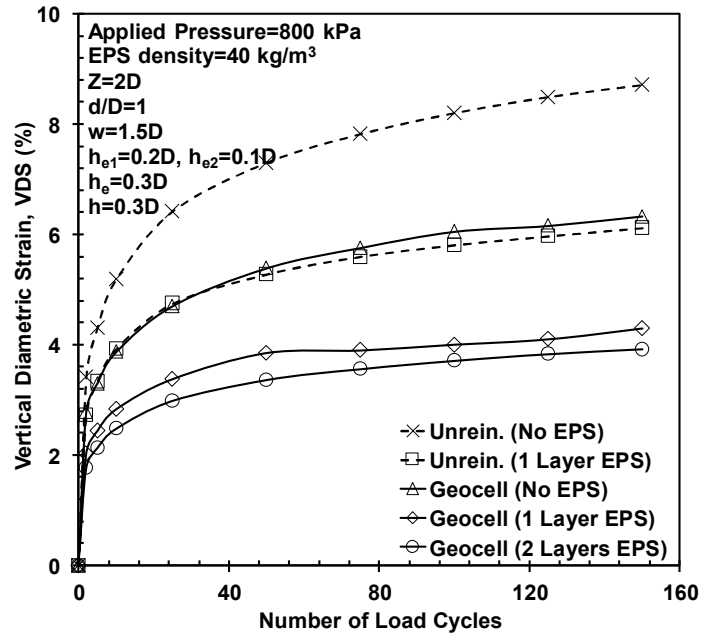

(a)

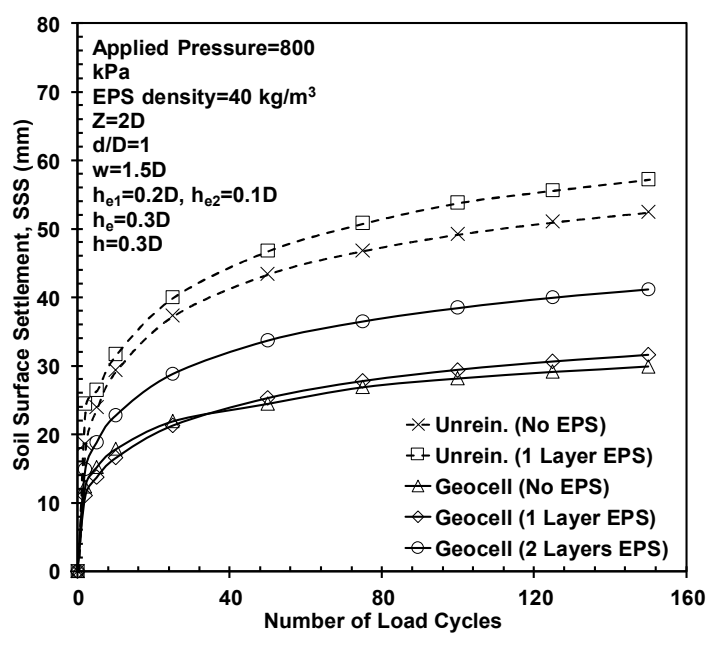

(b)

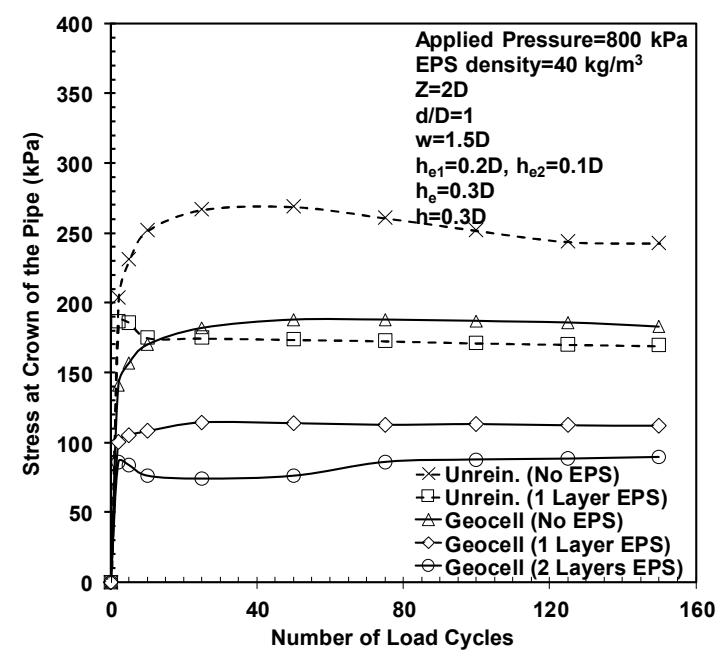

(c) 


\section{List of Figures}

\begin{tabular}{|c|c|}
\hline Fig. 1 & Grain size distribution curves for backfill soil (ASTM D 2487) \\
\hline Fig. 2 & $\begin{array}{l}\text { Schematic view of test setup, instrumentation positions and geometric parameters (unit } \\
\text { in mm) }\end{array}$ \\
\hline Fig. 3 & $\begin{array}{l}\text { (a) Schematic installation of LVDTs inside the pipe and pressure cell on the crown of } \\
\text { pipe (unit in mm) (b) Photograph view of steel U channel solid base, magnet base/rod } \\
\text { and LVDTs inside the pipe }\end{array}$ \\
\hline Fig. 4 & $\begin{array}{l}\text { Photograph of (a) pipe installation in trench (b) EPS block installation over the pipe (c) } \\
\text { geocell layer used in experiments, partially filled with sand (d) test installation prior to } \\
\text { loading include reaction beam, load plate, hydraulic jack and LVDTs on loading plate }\end{array}$ \\
\hline Fig. 5 & $\begin{array}{l}\text { Schematic view of (a) unreinforced backfill without EPS block, (b) unreinforced backfill } \\
\text { with EPS block, (c) geocell reinforced backfill with one layer of EPS block (d) geocell } \\
\text { reinforced backfill with two layers of EPS block }\end{array}$ \\
\hline Fig. 6 & $\begin{array}{l}\text { Typical trend of (a) hysteresis curve of VDS, (b) hysteresis curve of SSS, (c) VDS with } \\
\text { load cycles, (d) SSS with load cycles }\end{array}$ \\
\hline Fig. 7 & $\begin{array}{l}\text { The effect of load plate diameter and amplitude of applied repeated load on (a) } \\
\text { maximum values of VDS, (b) maximum values of SSS and (c) pipe crown pressure }\end{array}$ \\
\hline Fig. 8 & $\begin{array}{l}\text { The effect of embedment depth of pipe (1.5D and 2D) on maximum values of VDS and } \\
\text { SSS and pressure on crown under repeated pressure of } 800 \mathrm{kPa} \text { applied on a loading } \\
\text { surface diameter of } 250 \mathrm{~mm}(\mathrm{~d} / \mathrm{D}=1) \text { (a) VDS (b) SSS, (c) pressure on crown }\end{array}$ \\
\hline Fig. 9 & $\begin{array}{l}\text { The effect of EPS block width [repeated pressure of } 800 \mathrm{kPa} \text {; loading surface diameter } \\
\text { of } 250 \mathrm{~mm}(\mathrm{~d} / \mathrm{D}=1) \text { ] on (a) maximum values of VDS (b) maximum values of SSS, (c) } \\
\text { maximum pressure on pipe crown }\end{array}$ \\
\hline Fig. 10 & $\begin{array}{l}\text { The effect of EPS block density for an installation subjected to a repeated pressure of } \\
800 \mathrm{kPa} \text { applied on a loading surface diameter of } 250 \mathrm{~mm}(\mathrm{~d} / \mathrm{D}=1)(\mathrm{a}) \text { maximum values } \\
\text { of VDS (b) maximum values of SSS, (c) maximum pressure on pipe crown }\end{array}$ \\
\hline Fig. 11 & $\begin{array}{l}\text { Variation of maximum values of VDS and SSS and pressure on crown with number of } \\
\text { load cycles, for different installations [repeated pressure of } 800 \mathrm{kPa} \text {; loading surface } \\
\text { diameter of } 250 \mathrm{~mm}(\mathrm{~d} / \mathrm{D}=1) \text { ] (a) VDS (b) SSS, (c) pressure on crown }\end{array}$ \\
\hline Fig. 12 & $\begin{array}{l}\text { Longitudinal vertical deformation profiles for installations of unreinforced and geocell } \\
\text { reinforced backfill with } 2 \text { layers of EPS block (unit in } \mathrm{mm} \text { ) }\end{array}$ \\
\hline
\end{tabular}

